University of South Florida

DIGITAL COMMONS

Digital Commons @ University of

@ UNIVERSITY OF SOUTH FLORIDA

South Florida

7-15-1991

\title{
On the Seasonal Phytoplankton Concentration and Sea Surface Temperature Cycles of the Gulf of Mexico as Determined by Satellites
}

\author{
Frank E. Muller-Karger \\ University of South Florida, carib@usf.edu \\ John J. Walsh \\ University of South Florida, jwalsh@usf.edu \\ Robert H. Evans \\ University of Miami \\ Mark B. Meyers \\ University of South Florida
}

Follow this and additional works at: https://digitalcommons.usf.edu/msc_facpub

Part of the Marine Biology Commons

\section{Scholar Commons Citation \\ Muller-Karger, Frank E.; Walsh, John J.; Evans, Robert H.; and Meyers, Mark B., "On the Seasonal Phytoplankton Concentration and Sea Surface Temperature Cycles of the Gulf of Mexico as Determined by Satellites" (1991). Marine Science Faculty Publications. 78. \\ https://digitalcommons.usf.edu/msc_facpub/78}

This Article is brought to you for free and open access by the College of Marine Science at Digital Commons @ University of South Florida. It has been accepted for inclusion in Marine Science Faculty Publications by an authorized administrator of Digital Commons @ University of South Florida. For more information, please contact digitalcommons@usf.edu. 


\title{
On the Seasonal Phytoplankton Concentration and Sea Surface Temperature Cycles of the Gulf of Mexico as Determined by Satellites
}

\author{
Frank E. Müller-Karger and John J. Walsh
}

Department of Marine Science, University of South Florida, St. Petersburg

\author{
ROBERT H. EVANS
}

Rosenstiel School of Marine and Atmospheric Science, University of Miami, Miami, Florida

\author{
MARK B. Meyers
}

Department of Marine Science, University of South Florida, St. Petersburg

\begin{abstract}
Monthly climatologies of near-surface phytoplankton pigment concentration and sea surface temperature (SST) were derived for the Gulf of Mexico from multiyear series of coastal zone color scanner (CZCS) (November 1978 to November 1985) and advanced very high resolution radiometer (AVHRR) (January 1983 to December 1987) images. We complement these series with SST from the comprehensive ocean-atmosphere data set (1946-1987) and Climate Analysis Center (1982-1990), and hydrographic profile data from the NOAA National Oceanographic Data Center (1914-1985). The CZCS ocean color satellite data provide the first climatological time series of phytoplankton concentration for the region. The CZCS images show that seasonal variation in pigment concentration seaward of the shelf is synchronous throughout the gulf, with highest values $\left(>0.18 \mathrm{mg} \mathrm{m}^{-3}\right)$ in December to February and lowest values $\left(\sim 0.06 \mathrm{mg} \mathrm{m}^{-3}\right)$ in May to July. Variation in SST is also synchronous throughout the gulf, with maxima in July to September and minima in February to March. The amplitude of the SST variation in the western gulf is about twice that observed in the eastern gulf, and SST maxima and minima persist longer in the west. Larger amplitudes in SST variation are also observed toward the margins. While annual cycles of SST and pigment concentrations are out of phase relative to each other, the phases of mixed layer depth change and pigment concentration change are similar. Model simulations suggest that the single most important factor controlling the seasonal cycle in surface pigment concentration is the depth of the mixed layer. The combined use of ocean color and infrared images permits year-round observation of spatial structure of the surface circulation in the gulf and the pattern of dispersal of the Mississippi River plume. Infrared images are most useful between November and mid-May, when strong SST gradients occur. During this time, pigment concentrations are high and can be horizontally homogeneous. In contrast, between late May and October, SST fields are uniform, but the Loop Current and large anticyclonic eddies could be traced with the CZCS. Three anticyclonic eddies were observed in 1979, and at least two were observed in 1980 . No eddies were observed during summers of subsequent years in the CZCS time series, but this may be a result of the dramatic decrease in the satellite sampling rate. The series of color images showed that small parcels of Mississippi River water were frequently (2-4 times a year) entrained in the cyclonic edge of the Loop Current, stretched along the Current, and carried to the southeast along the western Florida shelf. However, most of the Mississippi River water flowed to the west, following the Louisiana-Texas coast as far south as the Mexico-United States border. Here, a persistent cyclone may reside, exporting shelf constituents to deeper regions of the gulf.
\end{abstract}

\section{INTRODUCTION}

The Gulf of Mexico (Figure 1) has been the focus of extensive physical oceanographic field and modeling studies [Austin, 1955; Nowlin et al., 1968; Nowlin, 1972; Nowlin and Hubertz, 1972; Wert and Reid, 1972; Robinson, 1973; Schroeder et al., 1974; Sturges and Blaha, 1976; Paluszkiewicz et al., 1983; Blumberg and Mellor, 1985; Hofmann and Worley, 1986; Pechmann et al., 1986; Kirwan et al., 1988]. The main attractions have been the warm Loop Current and the large (100- to $200-\mathrm{km}$ diameter) anticyclonic rings repeatedly shed by this current [Vukovich et al., 1979; Vukovich and Maul, 1985; Vukovich, 1986, 1988a; Elliott,

Copyright 1991 by the American Geophysical Union.

Paper number 91JC00787.

0148-0227/91/91JC-00787\$05.00
1982; Auer, 1987; Kirwan et al., 1984a, b; Lewis and Kirwan, 1987]. However, compared to the knowledge that has accumulated about physical processes in the gulf, very little is known about the biological oceanography of the region.

Most biological oceanographic studies in the Gulf of Mexico have been geographically restricted [e.g., Ortner et al., 1984; Biggs et al., 1984, 1991], and only one attempt to carry out a synoptic ship survey of the phytoplankton distribution in the gulf has been made [El-Sayed and Trees, 1980]. It took 30 days to complete the latter survey (February 25 to March 27, 1980), and the extreme eastern and southeastern gulf were not sampled. Trees [1985] produced a contoured map of chlorophyll $a$ from this survey, but no clear patterns emerged. Furthermore, he found no apparent relationship between the contoured data and pigment con- 


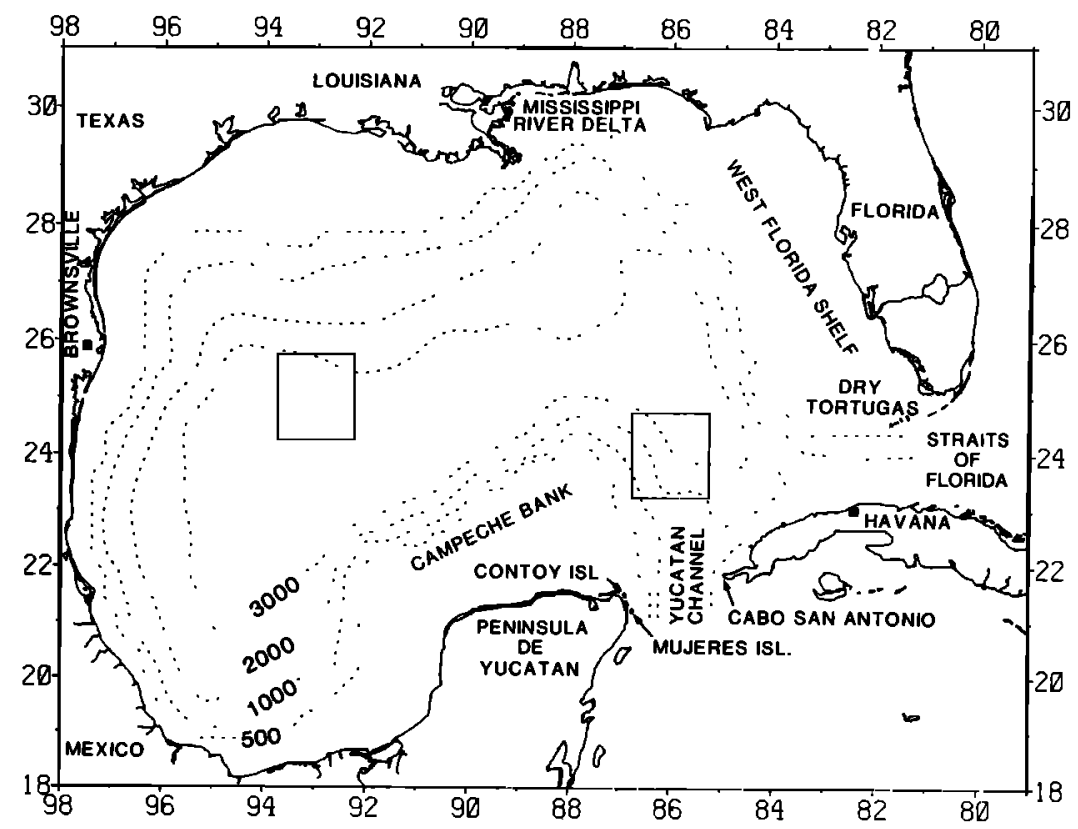

Fig. 1. Schematic map of the Gulf of Mexico showing areas for which time series of pigment concentration and sea surface temperature were extracted: entire basin, eastern gulf (Loop Current waters, $200 \times 200-\mathrm{km}^{2}$ box, centered at $24^{\circ} \mathrm{N}, 86^{\circ} \mathrm{W}$ ), and western gulf (modified Gulf of Mexico waters, $200 \times 200-\mathrm{km}^{2}$ box, centered at $25^{\circ} \mathrm{N}, 93^{\circ} \mathrm{W}$ ).

centration fields inferred from four single coastal zone color scanner (CZCS) satellite images collected during the survey. Maul et al. [1984] also attempted to use CZCS data (among other remotely sensed information) in an effort to compare spatial patterns of catch per unit effort for Atlantic bluefin tuna in the Gulf of Mexico with spatial patterns in oceanographic variables but he could not use any of the data covering the sampled fishery periods on account of cloudiness or location.

Walsh et al. [1989] reviewed the available phytoplankton and nutrient data in an effort to validate a coupled physicalbiological numerical model for the Gulf of Mexico. In their model of the biological response to eddy shedding and nutrient injection by the Loop Current, incident light and vertical mixing varied seasonally. The simulated phytoplankton concentrations also followed a well-defined seasonal cycle. Walsh et al. [1989], however, found that historical in situ data were scarce and insufficient to validate the model results. Nevertheless, carbon deposition patterns observed in sediments of the Gulf of Mexico as well as more recent surface chlorophyll concentration distribution patterns, observed in a preliminary time series of CZCS images at $20-\mathrm{km}$ resolution, were reproduced by the model.

This is a companion paper to the numerical simulation of the Gulf of Mexico by Walsh et al. [1989]. Our primary goals in this study were to (1) derive the climatological seasonal cycle of pigment concentration in the gulf, needed for basic validation of numerical simulations; (2) examine the spatial and temporal variability of the surface distribution of phytoplankton in the region; (3) determine the main factor(s) controlling the observed spatial and temporal changes in pigment concentration in the interior of the gulf; (4) derive a climatology of sea surface temperature (SST) based on infrared satellite data and validate it using historical in situ information; (5) show that a combination of infrared and ocean color space-based sensors can provide year-round observations on the spatial structure of the surface circulation in the region; and (6) trace the general pattern of dispersal of the Mississippi River plume.

\section{MeTHODS}

\section{Pigment Concentrations}

Synoptic estimates of the concentration of pigments in surface waters of the Gulf of Mexico were derived using the CZCS, launched by NASA on the Nimbus 7 satellite in October 1978. The CZCS was an experimental sensor that provided an estimate of the water-leaving radiance originating in the first optical depth. The average phytoplankton concentration in this layer has been empirically related to the water-leaving radiance, and thus at low concentrations (0.04-0.5 mg pigment $\mathrm{m}^{-3}$ ) the CZCS-derived pigments represent the optically weighted average algae biomass within a surface layer of approximately $1-$ to $10-\mathrm{m}$ depth.

The CZCS data were screened with the BROWSE quicklook facility developed at the Goddard Space Flight Center by G. Feldman and N. Kuring. Only scenes which covered at least some portion of the Gulf of Mexico containing patches of valid data greater than approximately $200 \times 200$ km were selected. Pigment concentrations were obtained at a spatial resolution of approximately $4 \mathrm{~km}$ by subsampling the original CZCS images to $1 / 16$ of their original resolution at NASA's Goddard Space Flight Center (GSFC), Greenbelt, Maryland [see Feldman et al., 1989]. Concentrations were derived from ratios of the blue $(443 \mathrm{~nm})$ or blue-green $(520 \mathrm{~nm})$ water-leaving radiances to the green radiance (550 $\mathrm{nm}$ ), using the atmospheric correction and bio-optical algorithms of Gordon et al. [1983a] (also see Gordon et al. [1983b] and Gordon et al. [1988]). Clouds were masked using a simple threshold test on the 750-nm band (channel 5). The threshold was selected as the value where the CZCS visible 


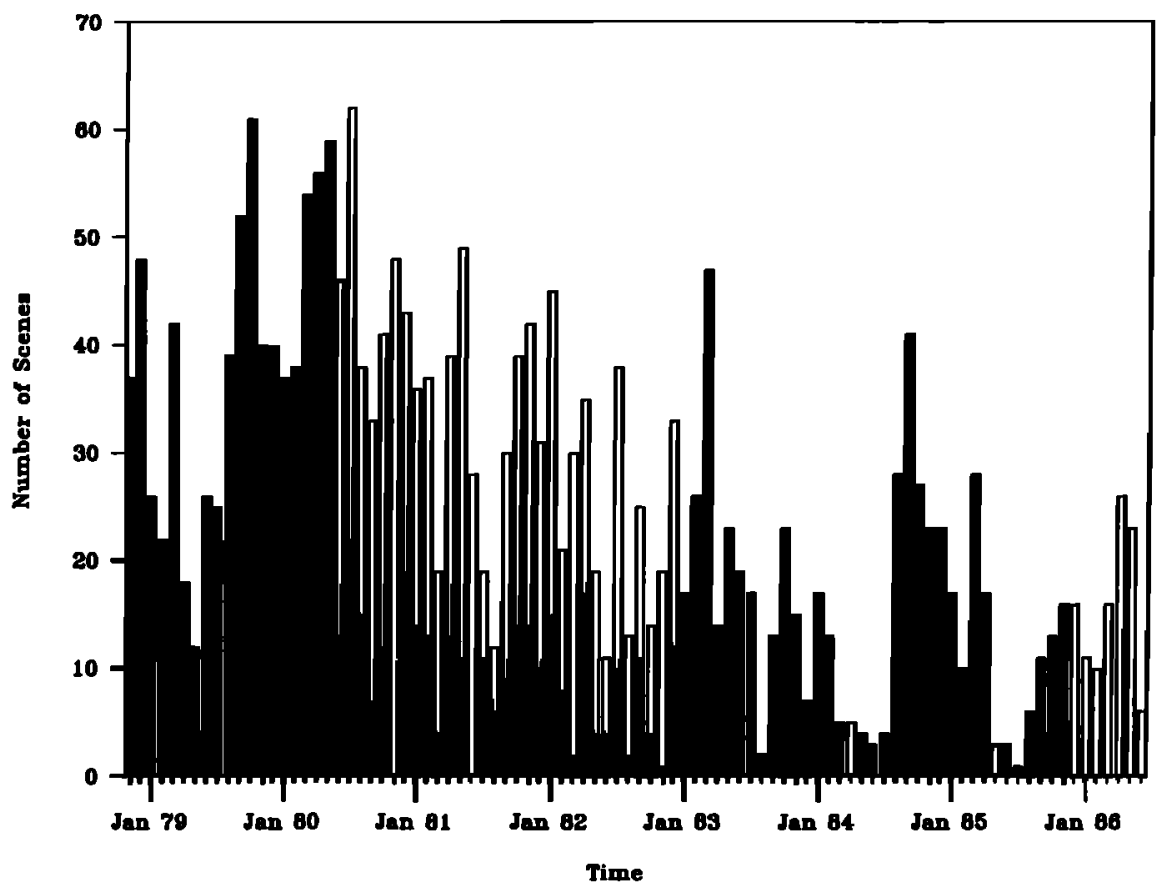

Fig. 2. Temporal coverage of the Gulf of Mexico realized during the lifetime of the CZCS (November 1978 to June 1986, open bars), as well as temporal coverage of data used for this study (November 1978 to November 1985, solid bar overlays). The CZCS data were screened with the BROWSE quick-look facility developed at the Goddard Space Flight Center by G. Feldman and N. Kuring. Only scenes which covered at least some portion of the Gulf of Mexico containing patches of valid data greater than approximately $200 \times 200 \mathrm{~km}$ were selected. Consecutive 2-min segments from one satellite pass were counted as separate scenes. Data used in this study were binned into monthly means as described in the text (see Plate 1).

channels, particularly the 670-nm band (channel 4), begins to saturate, a point at which atmospheric correction is no longer possible. The processed CZCS data also include a mask for Sun glint.

Coherent spatial patterns of pigment concentration in the gulf could not be discerned using individual CZCS images or even weekly composites owing to extensive cloud cover or lack of programed coverage (see, for example, Trees [1985]). Therefore we binned the data into monthly composites. All images were first mapped to congruent cylindrical equidistant projections. Binning used all available cloud-free pixels for a month, generating fields with $\operatorname{sum} X, \operatorname{sum} X^{2}$, and $N$ for each pixel. Daily fields were converted into fields representing arithmetic average pigment concentration, standard deviation, and number of scenes available within the given time interval (see below). Valid pixels were those having pigment concentrations between 0.04 and $7.0 \mathrm{mg} \mathrm{m}^{-3}$; i.e., we excluded missing data, clouds, and extremely high pigment values. The resulting composite images had the same spatial resolution as the input images. Clearly, locations affected by clouds or missing data in successive images resulted in smaller temporal bins relative to locations with valid data.

Composites for November 1978 through May 1980 represent calendar monthly means. These data were binned at spatial resolutions of $4 \mathrm{~km}$. Subsequent composites through December 1981 were based on the first 10 days of consecutive 30-day periods, which clearly represents only a fraction of the available data (see Figure 2). We binned these data into $20-\mathrm{km} \times 20-\mathrm{km}$ squares prior to deriving composites. From January 1982 through December 1985, composites represent 30-day means of all CZCS data collected during that time. The resolution of this latter set was further reduced to approximately $36 \mathrm{~km} \times 30 \mathrm{~km}$ per pixel. The reduction of spatial and of temporal resolution as described was arbitrary and was done to help alleviate computer mass storage restrictions. We believe that this scheme still provides first-order estimates of the monthly means.

To examine time variation in the concentration of phytoplankton, we obtained arithmetic means for the three areas shown in Figure 1:

Entire Gulf of Mexico. This area included all waters within the gulf to a line across the Yucatan Channel (between Isla Mujeres off Yucatan and Cabo San Antonio, Cuba) and a line across the Straits of Florida (extending along $81^{\circ} \mathrm{W}$ ). Three means were derived for each month: a mean including continental shelf waters, a mean based only on waters deeper than the continental shelf and a shelf mean. A shelf mask for waters shallower than $200 \mathrm{~m}$ was obtained from a digital, $0.5-\mathrm{min}$ resolution bathymetric data set from the Naval Ocean Research and Development Activity (NORDA) in Stennis Space Center, Mississippi.

Eastern gulf. This area included a box $200 \times 200 \mathrm{~km}^{2}$ centered at $24^{\circ} \mathrm{N}, 86^{\circ} \mathrm{W}$, containing Loop Current water.

Western gulf. This area included a box $200 \times 200 \mathrm{~km}^{2}$ centered at $25^{\circ} \mathrm{N}, 93^{\circ} \mathrm{W}$, containing modified Gulf of Mexico water.

From these series we further derived a 7-year monthly climatology for each region by averaging by month across years.

To test the effects of spatial resolution on the regional means derived from the CZCS data, we compared monthly composites derived in four different ways for the period 
November 1978 through May 1980. This period was chosen because it was the only one for which we had a complete 4-km resolution data set at the time of the study. Specifically, we computed four versions of the monthly mean concentration for the $200 \times 200-\mathrm{km}$ box located in the eastern Gulf of Mexico (Figure 1), as follows: (1) Regional means were computed directly from the $20-\mathrm{km}$ resolution CZCS monthly composites of the North Atlantic generated by G. Feldman (NASA GSFC) and described by $\mathbf{M c C l a i n}$ et al. [1990]. (2) Regional means were computed directly from the 4-km resolution CZCS monthly composites of the Gulf of Mexico. (3) Using the daily 4-km resolution CZCS images of the Gulf of Mexico, the monthly means were computed by averaging the series of daily regional means. (4) Using the daily 4-km resolution CZCS images of the Gulf of Mexico, the monthly means were computed by weighting the daily regional means by the number of valid pixels in each daily image (valid pixels are those with valid data).

We found that there were no significant differences between these series using a simple $t$ test on month-to-month differences between any pair of series. The null hypothesis tested was that the population of differences had an average value of 0 . The test criterion was that of significance at the $0.1 \%$ level or better. In summary, all versions provided the same result regardless of how they were derived.

There may be problems in applying simple statistical tests, such as the $t$ test used here, to satellite images of geophysical data. This is because such data are frequently spatially correlated (and therefore not independent). It is also hard to estimate degrees of freedom and standard errors. The $t$ test is not statistically rigorous for the comparisons attempted here because phytoplankton biomass does not follow a normal distribution in space but rather follows a lognormal distribution [see Campbell and $O^{\prime}$ Reilly, 1988]. Also, sample size of the populations of means was different for each of the series just compared, simply as a result of the way in which the means were derived. Nevertheless, such comparisons suggest that differences in the series for the deep waters of the Gulf of Mexico, derived in radically different ways, are small.

This differs from the conclusion of Müller-Karger et al. [1989], who in a study of the Caribbean Sea found that the most robust series of means was obtained using the weighted daily means. The reason that this method did not provide different results for the Gulf of Mexico is that the areas examined by Müller-Karger et al. [1989] were very large $\left(>10^{5} \mathrm{~km}^{2}\right)$ relative to the $200 \times 200-\mathrm{km}$ boxes used here, and within those areas of the Caribbean examined, patches of high concentrations occurred periodically as a result of the dispersal of river plumes or upwelling. Under such conditions, partial coverage of the sampling areas by the CZCS led to biases in the regional means, and weighting reduced the impact of the outlying values on the mean.

On the other hand, the use of imagery of varying resolution may not provide equivalent results for studies of smallscale processes, i.e., over scales much smaller than the $\mathbf{2 0 0}$ $\times 200-\mathrm{km}$ boxes used here. At such small scales it is best to use full resolution imagery (1-km pixels in the case of the CZCS and the advanced very high resolution radiometer (AVHRR)). Subsampling of the original data by factors of 16 or more, as was done here, with subsequent grouping into bins of $20 \mathrm{~km}$ or larger, aliases (or filters) small-scale features from the data.
It is clear that the nature of the data set used has to be well understood. It is not uncommon to find low-resolution data sets, such as global CZCS images with a nominal pixel resolution of $18-20 \mathrm{~km}$ (i.e., $2048 \times 1024$ pixel images), further degraded by a factor of 8 for digital display on $512 \times$ 512 pixel screens, being used as if they had not been subsampled. Such data are inadequate to study local, smallscale phenomena.

In terms of the accuracy of the concentrations derived, previous results suggest that in low-pigment waters $(0.08-1.5$ $\mathrm{mg} \mathrm{m}^{-3}$ ), retrieved pigment concentrations are within 30$40 \%$ of in situ concentrations [Gordon et al., 1980, 1982, 1983a]. The deep Gulf of Mexico falls in this category, with waters of case I type [see Morel and Prieur, 1977]. However, the accuracy of derived values is questionable over shelf waters and in areas of river plume dispersal [see MüllerKarger et al., 1989; Carder et al., 1989], even though CZCS pigment values in areas affected by rivers may be realistic [Yoder et al., 1987; Barale et al., 1986; Gordon et al., 1983a]. Such areas have been broadly classified as being case II by Morel and Prieur [1977], to indicate that there may be a large concentration of gelbstoffe (yellow dissolved organic matter) as well as other marine or terrigenous constituents which do not covary with phytoplankton.

The presence of additional colored constituents can lead to an overestimate of phytoplankton concentration [see Baker and Smith, 1982; Carder et al., 1986]. The degree of correlation among phytoplankton, suspended matter, and gelbstoffe near the Mississippi River delta or the nearshore environment of the Gulf of Mexico is unclear, and in such environments it is difficult to quantify chlorophyll concentration based on a simplistic blue-green ratio of CZCS radiances [e.g., Fisher et al., 1986]. The algorithms used here did not compensate for the presence of these additional constituents. It is important that future studies refine our present ocean color algorithms using extensive direct ground information [e.g., Carder et al., 1986, 1989; also R. R. Bidigare et al. (Influence of the Orinoco River outflow on distributions of algal pigments in the Caribbean Sea, submitted to Journal of Geophysical Research, 1991)] and indirect mass balance models [e.g., Müller-Karger et al., 1989] in order to accurately quantify carbon pools and concentrations of other optical constituents.

An additional source of error in the CZCS data is a "ringing" (sensor overshoot) effect caused by a lag in the adjustment of the CZCS amplifiers to large changes in target brightness off the eastern and northeastern boundaries (downscan side) of some clouds [see Mueller, 1988]. Ringing effects were minimized in our $20-\mathbf{k m}$ spatial resolution products by masking of affected areas prior to the spatial binning process. Mask generation relied both on the properties of the CZCS and the behavior of the normalized water-leaving radiance at $520 \mathrm{~nm}$ (band 2). The nominal value of normalized water-leaving radiance at $520 \mathrm{~nm}$ is $0.48 \mathrm{~mW} \mathrm{~cm} \mathrm{~mW}^{-2}$ $\mu \mathrm{m}^{-1} \mathrm{sr}^{-1}$. This decreases with increasing chlorophyll concentration (see, for example, Figure 2 of Gordon et al. [1988]). The 520-nm CZCS channel exhibited the lowest instrument noise of any of the CZCS bands but suffered a large overshoot response. A threshold of $0.7 \mathrm{~mW} \mathrm{~cm}$ $\mu \mathrm{m}^{-1} \mathrm{sr}^{-1}$ was chosen to allow for in-water scattering and residual aerosol radiance. Once the atmospherically corrected 520-nm radiances decreased below 0.7 , a subsequent test required the pixel-to-pixel radiance difference to be less 
than $0.10 \mathrm{~mW} \mathrm{~cm}^{-2} \mu \mathrm{m}^{-1} \mathrm{sr}^{-1}$ (approximately two instrument counts). A distance limit restricted the test to pixels within $\mathbf{4 0}$ original resolution pixels of the cloud edge determined with the 750-nm band as was explained above.

Note that we corrected the sensor overshoot artifacts when deriving the $20-\mathrm{km}$ spatially binned data but for comparison purposes did not apply this correction to the 4-km CZCS products discussed below. Similar to what was found by Müller-Karger et al. [1990], the geographical area affected by ringing in the Gulf of Mexico was small relative to our area of study, affecting a band of the order of $10 \mathrm{~km}$ or less on the downscan side of clouds. Below we show that there were no statistical differences between the regional means derived using the 20 - or the 4-km data sets, in spite of the different masks applied.

\section{Sea Surface Temperature}

To complement the pigment time series, we examined SST fields derived from the NOAA operational multichannel sea surface temperature (MCSST) product archived at the University of Miami [Olson et al., 1988]. The SST values are derived from AVHRR data and distributed by NOAA (global retrieval tapes). The NOAA product consists in lists of latitude, longitude, time, and MCSST. MCSST techniques are described by Walton [1988], Strong and McClain [1984], and $M c$ Clain et al. [1983]. The algorithms used were those of McClain et al. [1985]. These include a series of tests, using radiance thresholds for visible channels and differences of brightness temperatures for the infrared channels, to detect cloud-contaminated pixels. The data were sorted by time and grouped into 2-week bins for 1982-1986 and into 1-week bins starting in 1987 . Subsequently, data points were geographically binned into pixels of a $2048 \times 1024$ matrix covering the globe (cylindrical equidistant projection). A Laplacian interpolation was used to fill gaps, with the condition that one valid retrieval exist within nine pixels of the pixel being evaluated. For purposes of this work we focused on the Gulf of Mexico and the northwestern Caribbean Sea. We derived SST climatologies for the subregions shown in Figure 1 by binning data by month across years.

We also examined multiyear series of SST extracted from the comprehensive ocean-atmosphere data set (COADS) and the Climate Analysis Center (CAC) data set. Both of these data sets are archived and described in the on-line NASA climate data system (NCDS) of the NASA Space Science Data Center (NSSDC) at NASA GSFC.

The COADS is described by Woodruff et al. [1987]. It contains monthly averaged marine observations for the years 1854 through 1987 on a $2^{\circ} \times 2^{\circ}$ geographical grid. We used the SST subset for the years 1946-1987. The COADS is derived from weather observations taken near the ocean's surface, primarily from merchant ships, and is supplemented by data from buoys, surface level bathythermographs, the global telecommunication system (GTS), and ocean station vessel observations. We used COADS to derive an additional SST climatology for the interior of the Gulf of Mexico by binning monthly data across the years.

The CAC SST was derived from in situ (ship-ofopportunity and fixed buoy) data and radiance data collected from the AVHRR. The AVHRR retrievals were derived by the multichannel technique referred to by Reynolds [1988]. The CAC SST data set [Reynolds, 1988; Reynolds and
Roberts, 1987] contains gridded $\left(2^{\circ} \times 2^{\circ}\right)$ SSTs and corresponding quality parameters, indicating whether the data is only from in situ or from blended SST observations (in situ SSTs blended with AVHRR-derived SSTs). Here, we used the blended analysis grids, which are available from January 1982 to December 1990. The CAC data have been subjected to objective quality controls as described by Reynolds [1988]. The global monthly average bias error is less than $0.1^{\circ} \mathrm{C}$. The global monthly average rms error is less than $0.8^{\circ} \mathrm{C}$. However, errors at individual grid points could be larger.

Finally, we derived mean monthly climatological profiles of temperature, salinity, and density $\left(\sigma_{t}\right)$ in the Gulf of Mexico using all standard depth NOAA National Oceanographic Data Center (NODC) station cast data for bottom depths $>50 \mathrm{~m}$ available for the gulf (period 1914-1985). The NODC data have limitations in terms of the spatial distribution of observations in the Gulf of Mexico. The highest density of observations is found in the Yucatan Channel and Straits of Florida along the west Florida shelf, and immediately east of the Mississippi delta. The rest of the gulf is more or less uniformly covered, with at least one station within $\mathbf{2 0}$ $\mathrm{km}$ of any other stations. The lowest density of stations is found in the southwestern quadrant of the gulf. We attempted deriving a climatology of nutrient concentration profiles, but the data archived for the gulf were so few and unreliable that it was not possible to interpret the results in a meaningful way.

\section{Results}

\section{Data Distribution}

We derived a total of 81 composite CZCS images representing a series of monthly mean pigment fields in the Gulf of Mexico from November 1978 through November 1985. This time series included 1562 individual scenes collected between November 1978 and November 1985 (the CZCS collected over 2500 scenes of the gulf over its lifetime; see Figure 2).

Figure 2 summarizes the temporal coverage of the Gulf of Mexico realized during the lifetime of the CZCS (November 1978 to June 1986), as well as the temporal coverage used for this study (November 1978 to November 1985). The total number of scenes included in a composite (Figure 2) is frequently slightly larger than the number of monthly CZCS passes that provided useful data. This occurs because CZCS data are archived in 2-min segments, and two or three consecutive segments collected during a single orbital pass were counted as separate scenes. Also, the total number of scenes used per binning period (Figure 2) is typically larger than the largest number of scenes included per pixel $(N)$ in a composite. This also is a consequence of scheduling and satellite position as well as variability in cloud cover.

The best sequence of images spanned 1979 and the first half of 1980 , the period over which $41 \%$ of the data examined were collected (Figure 2). Over $50 \%$ of the pixels in each of these monthly composites had a sample size larger than 2 , and on occasion, average sample sizes over the Gulf of Mexico and adjacent Cayman Sea exceeded five images per month per pixel (e.g., August, September, and October 1979 and March, April, and May 1980). In contrast, our temporal sampling scheme (10 days per month) for June 1980 through 


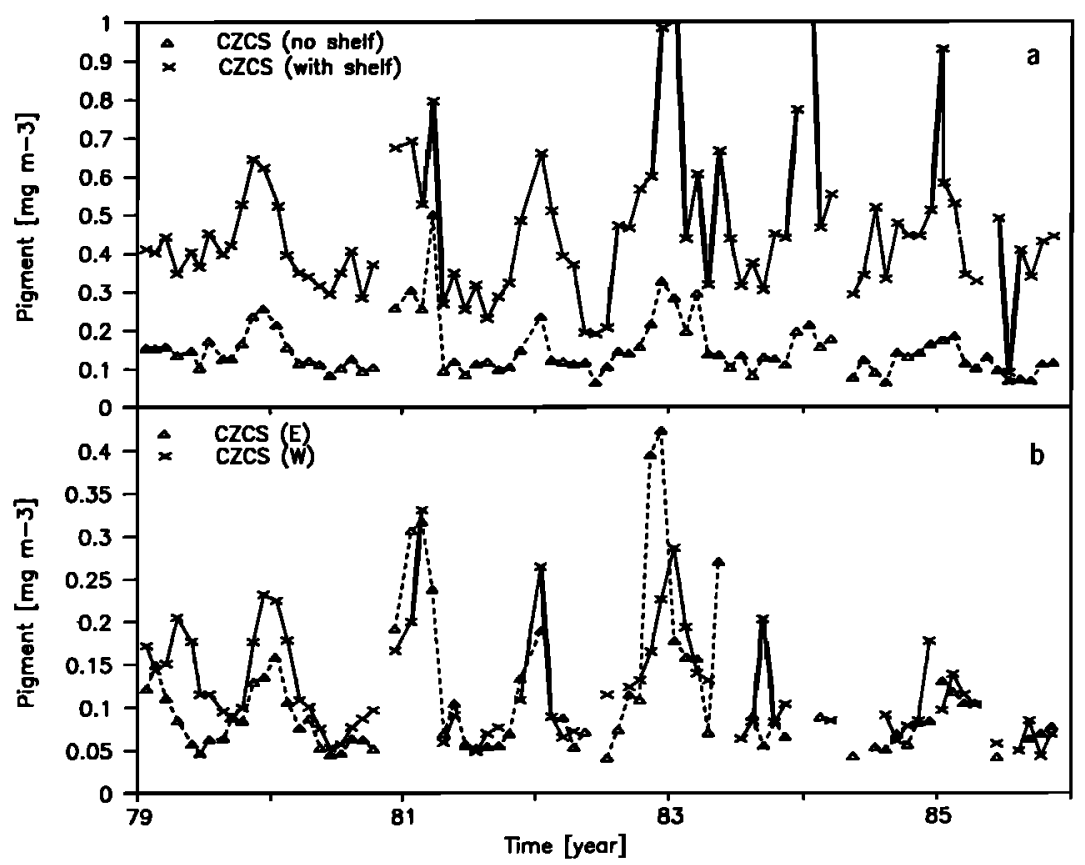

Fig. 3. Time series of regional monthly mean pigment concentration values in the Gulf of Mexico (milligrams per cubic meter). (a) Means derived for the entire basin: the solid curve shows the series which includes the continental shelf region; the dashed curve shows values obtained excluding the shelf. (b) Means derived for $200 \times 200-\mathrm{km}^{2}$ subregions shown in Figure 1: the solid curve represents the western box; the dashed curve shows the eastern box.

December 1982 resulted in markedly decreased coverage relative to the number of scenes available (Figure 2). Complete lack of coverage using the described sampling scheme occurred in November 1980, June 1981, April 1984, and May 1985.

It has been pointed out that cloud cover can alias time series of pigment fields [e.g., Abbott and Zion, 1987]. Clouds would preclude coverage of large portions of the Gulf of Mexico during periods of atmospheric front passage or during storm periods. Any transients of the near-surface pigment concentration resulting from storm activity may thus remain undetected by the CZCS. AVHRR-derived SST products would experience similar aliasing problem.

However, while we expected a strong seasonal pattern in the availability of CZCS data due to meteorological problems, the CZCS collected as many good data over the gulf during summers as during winters (e.g., Figure 2). In particular, the second half of 1979 and the first half of 1980 showed exceptionally good coverage of the gulf. It seems that more than cloud cover the reason for lack of coverage of the gulf was scheduling. In general, sample scheduling appears to have provided more frequent coverage of the eastern margin of the gulf: the dense coverage of the west Florida shelf is primarily the result of scheduling for data collection of the East Coast of the United States, with concomitant cover of this portion of the gulf.

A discussion of the distribution of clouds or cloud-free pixels in space or over time, and the aliasing effect of such variability on variations in ocean color, phytoplankton concentration, and sea surface temperature, is beyond the scope of the current study. This would require continuous coverage of the region and processing of the entire data set. Currently, it is difficult to separate the confounding factors of lack of data due to scheduling, geographical coverage during various orbital passes, data drops due to temporary sensor failure, and cloud cover.

\section{Phytoplankton Pigment Concentration Series}

Figure 3 shows the four time series of regional pigment means derived from the CZCS composites. Figure $3 a$ shows that there is an offset of $0.30 \mathrm{mg}$ pigment $\mathrm{m}^{-3}$ between the basin mean including the continental shelf (mean $=0.45 \mathrm{mg}$ pigment $\mathrm{m}^{-3}, \mathrm{SE}=0.18, n=80$ means) and the mean excluding the shelf (mean $=0.15 \mathrm{mg}$ pigment $\mathrm{m}^{-3}, \mathrm{SE}=$ $0.07, n=81$ means). Also, there clearly are higher values of algal biomass every boreal winter relative to the summer concentrations. Figure 3 also suggests that temporal variability over the shelf increased during 1983 and that the high winter concentrations in other regions of the gulf were attenuated after 1982. There is also a general lack of spatial and temporal pattern in the series of images starting in 1983. It is important to note that these time series are robust only up to about 1982, since afterward artifacts may have been introduced by the decrease in CZCS sampling. Furthermore, the calibration of the CZCS sensors after 1982 remains unknown. The climatologies derived here include the latter part of the record as well.

Figure $3 b$ shows the time series of monthly mean pigment concentrations within the two $200-\times 200-\mathrm{km}$ subregions of the gulf outlined in Figure 1. These subregions were chosen to examine the contrast between an offshore area directly influenced by the Loop Current and one that is not. Note that the eastern box is not necessarily always in the Loop Current. In particular, when anticyclonic eddies are shed, the Loop Current flows directly from Yucatan Channel through the Straits of Florida, i.e., south of the box. Accordingly, we expected variables measured in this box to show 


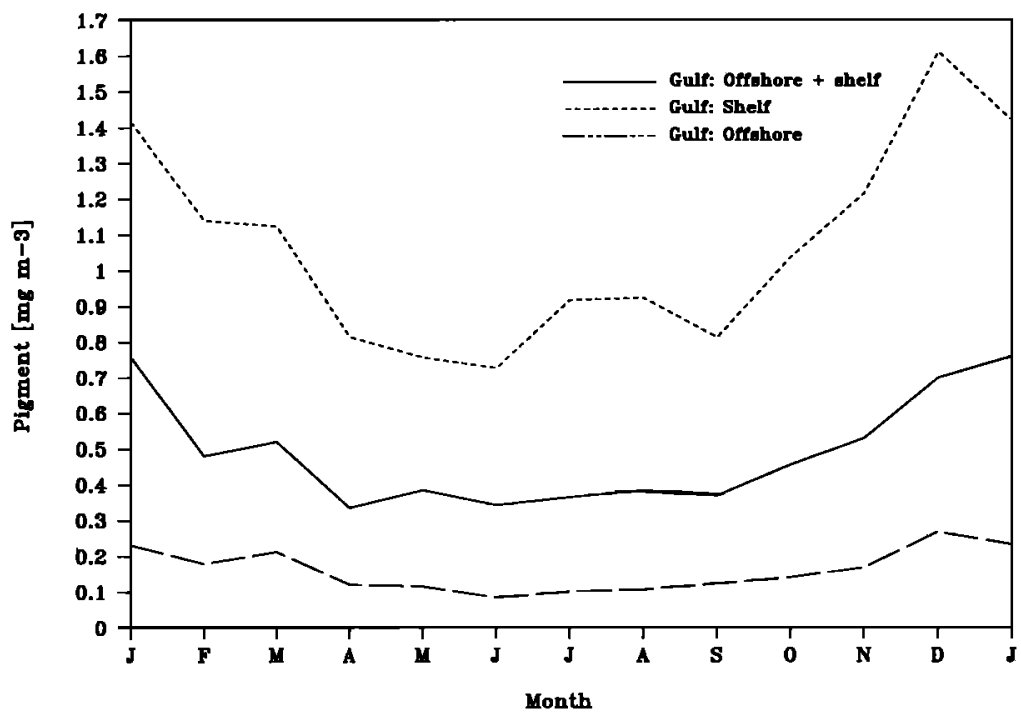

Fig. 4. Monthly climatology of pigment concentration (milligrams per cubic meter) in the Gulf of Mexico based on 7 years of CZCS data (1979-1985).

wide variability. In spite of this the eastern and western time series of algal biomass were very similar. Except for 1979 and late 1982 the subregion series tracked each other, showing that pigment variability in offshore waters is generally synchronous throughout the gulf at seasonal time scales.

Figure 4 shows the climatological seasonal cycle of pigment concentration in the Gulf of Mexico. The seasonal cycle for the continental shelf (waters shallower than $200 \mathrm{~m}$ ) was obtained by masking waters deeper than $200 \mathrm{~m}$. There is a seasonal cycle, both offshore and over the shelf, but it is clearly more pronounced over the shelf.

The climatological seasonal cycles of phytoplankton concentration in the two subregions of the Gulf of Mexico are shown in Figure 5. In both subregions, consistently low

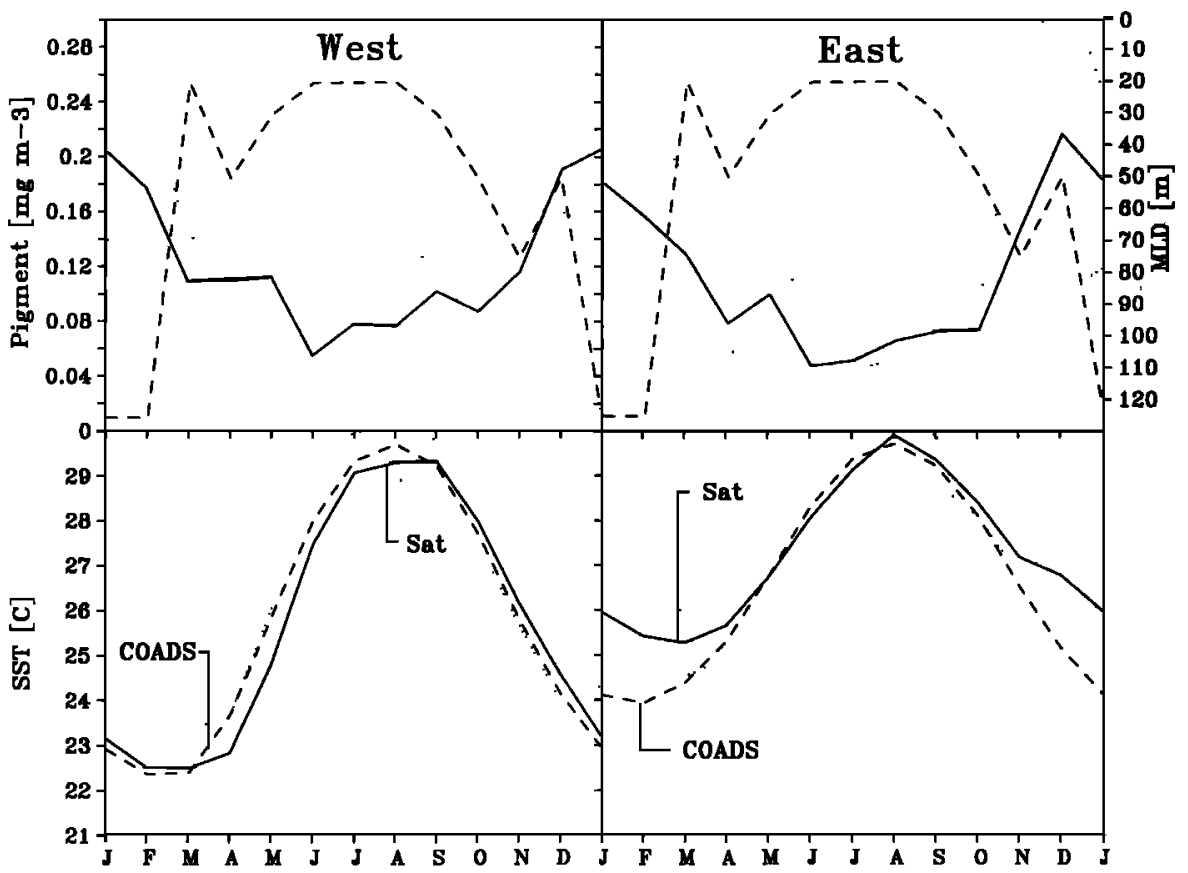

Fig. 5. Monthly climatology of pigment concentration (milligrams pigment per cubic meter) and sea surface temperature (degrees Celsius) within the two $200 \times 200 \mathrm{~km}^{2}$ subregions of the Gulf of Mexico shown in Figure 1. (Top) The solid curves represent a monthly pigment concentration climatology based on 7 years of CZCS data (1979-1985), and the dotted curves represent the standard error envelope of the series. The dashed curve overlay represents the climatological mixed layer depth, estimated from all historical NODC $\sigma$, data in the gulf (bottom depth $>50 \mathrm{~m}$; see text). (Bottom) Solid curves show monthly mean SST estimated from 5 years of AVHRR data (1983-1987), and the dotted curves represent the standard error envelope of the series. The dashed curves represent monthly mean SST values obtained from the COADS data set (1946-1987) for the $2^{\circ} \times 2^{\circ}$ boxes closest to the center of the subregions of interest. 


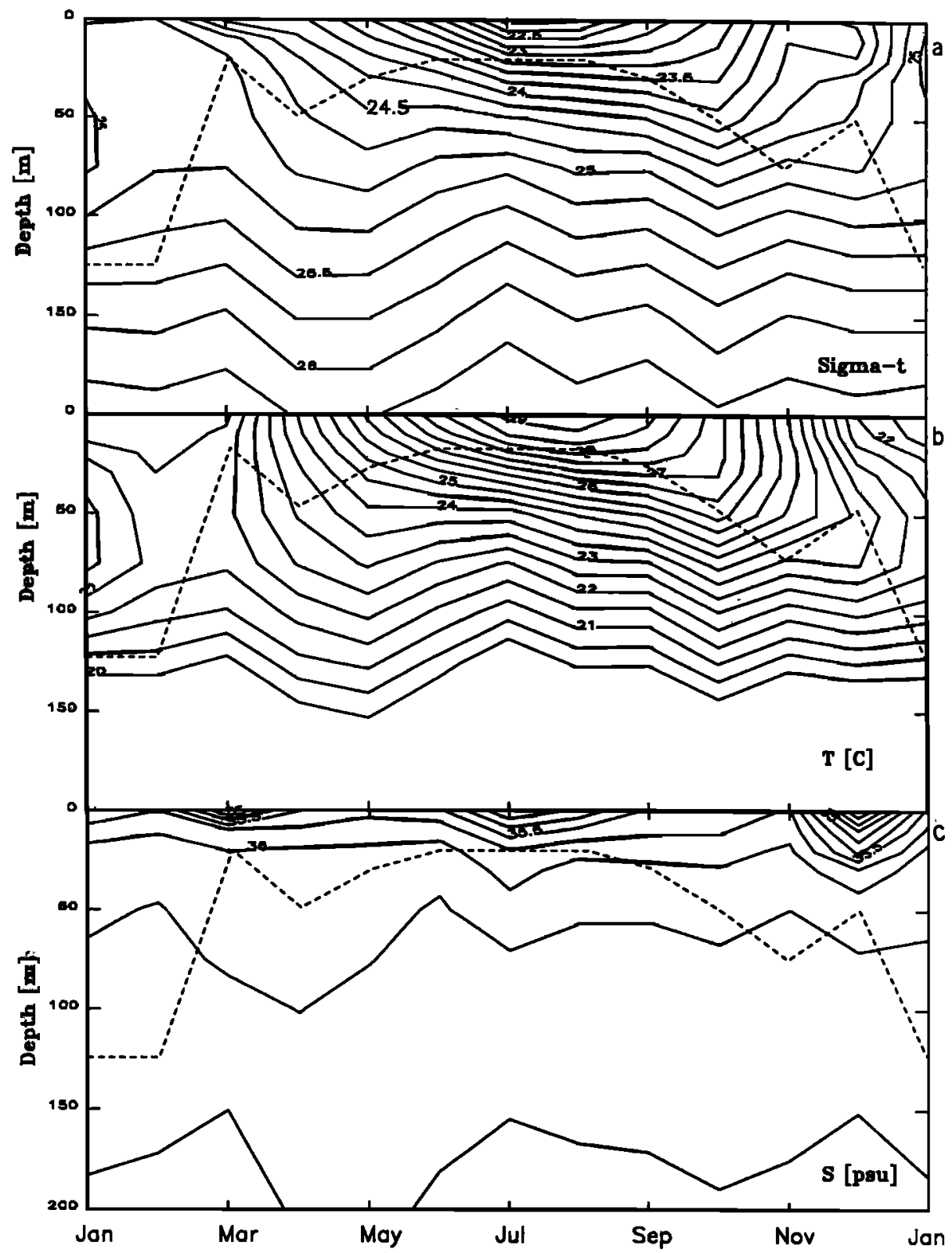

Fig. 6. The seasonal cycle of water column properties and mixed layer depth offshore in the Gulf of Mexico. The monthly climatology was derived from all the available NODC station data for the region with recorded water depths greater than $50 \mathrm{~m}:(a) \sigma_{t},(b)$ temperature, and (c) salinity. The ML.D (dashed curve overlay) was derived from the monthly climatological $\sigma_{t}$ profiles and defined as the first depth at which a change in $\sigma_{t}$ larger than 0.5 occurred relative to the mean density within the upper $10 \mathrm{~m}$.

pigment values occurred during summer (about $0.06 \mathrm{mg} \mathrm{m}^{-3}$ or less) and high values occurred during winter $(>0.18 \mathrm{mg}$ $\mathrm{m}^{-3}$ ). As was mentioned above, the cycles in both subregions are very similar. The eastern subregion, however, which is directly affected by the Loop Current, showed larger variability during late fall (November to December) than the western subregion. This appears to be the result of interannual variation in the chlorophyll concentration of waters flowing into the Gulf of Mexico from the Cayman Sear.

\section{Mixed Layer Depth and SST Series}

Figure 6 summarizes the seasonal cycle of water column properties in the offshore Gulf of Mexico. Monthly climato- logical $\sigma_{\imath}$ values (Figure 6a), temperature (Figure $6 b$ ), and salinity (Figure $6 c$ ) were derived at standard depths from all the available NODC station data for the region with recorded water depths greater than $50 \mathrm{~m}$ (years included: 1914-1985). The mixed layer depth (MLD) (shown in Figures 5 and 6) was defined as the first depth at which a change in $\sigma_{t}$ larger than 0.5 occurred relative to the mean density within the upper $10 \mathrm{~m}$, using the monthly climatological $\sigma_{t}$ profiles. Clearly, density in the upper $100 \mathrm{~m}$ undergoes a strong seasonal cycle which leads to shallow $(<20 \mathrm{~m})$ mixed layers during boreal summers. The density changes are largely the result of temperature changes.

Figure 7 shows the COADS and satellite-derived SST time series derived for the eastern and western subregions for the 


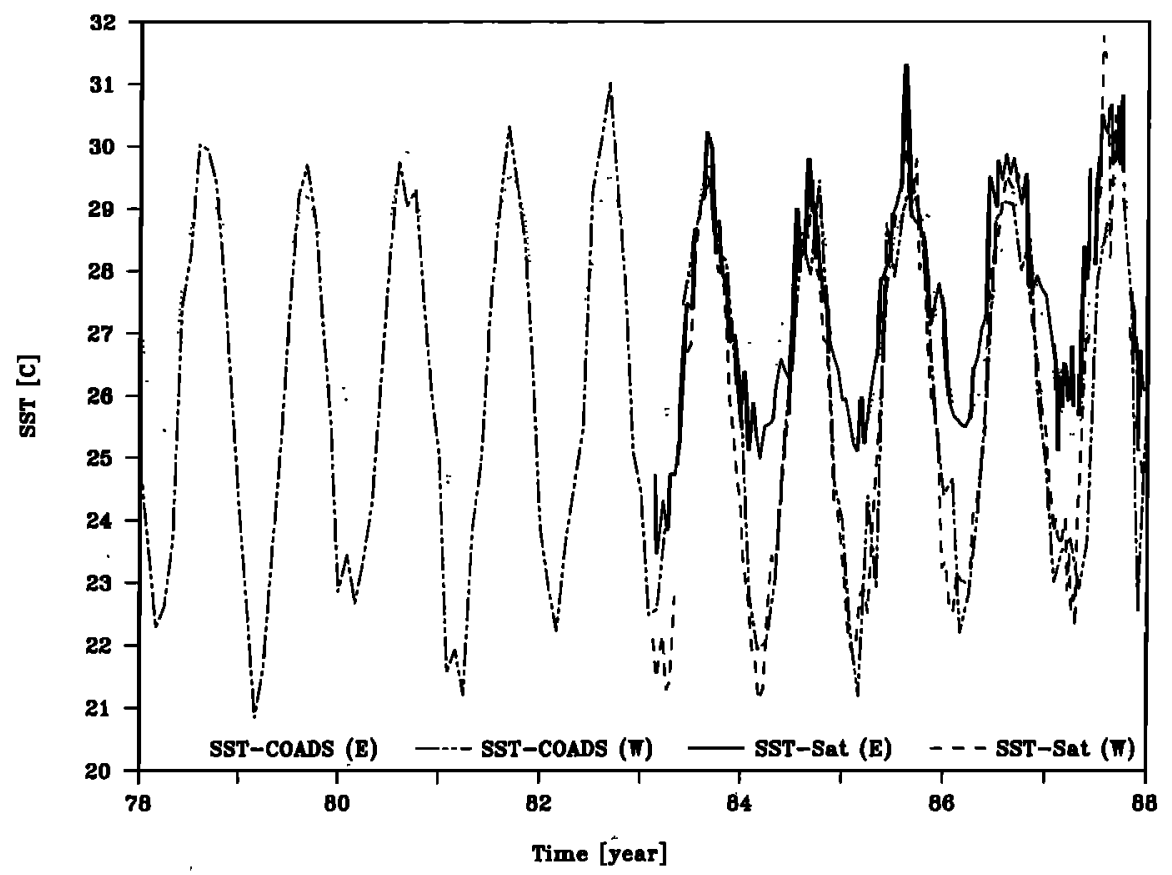

Fig. 7. Time series of SST $\left({ }^{\circ} \mathrm{C}\right)$ within the two $200 \times 200-\mathrm{km}^{2}$ subregions of the Gulf of Mexico shown in Figure 1. The series were derived from 5 yeats of AVHRR data (1983-1987) and from a subset (1978-1988) of the COADS data set for the $2^{\circ} \times 2^{\circ}$ boxes closest to the center of the subregions of interest.

period 1978-1988. In general, the COADS observations (1946-1987) suggested that interannual variation within the gulf is relatively small. This is also reflected in the narrow envelope of deviations from the monthly climatological SST means for the subregions (Figure 5) estimated both from the COADS (1946-1987) and from the AVHRR (1983-1987) data sets.

SST changes in the east and in the west were synchronous, but the amplitude of the seasonal variation was larger in the west (Figures 5 and 7). While between July and September both regions had relatively similar SSTs $\left(>29^{\circ} \mathrm{C}\right)$, from December through April the western subregion showed SSTs as much as $4^{\circ} \mathrm{C}$ lower than the eastern region. On the average, the mean SST range was about $7^{\circ} \mathrm{C}$ in the west, compared with about $5^{\circ} \mathrm{C}$ in the east. Also, SST maxima and minima in the west persisted for longer periods than maxima and minima in the east. The dampening of the seasonal variation in the east is caused by the influx of warm Caribbean water into the gulf via the Loop Current during winters; this water is warmer than western gulf waters. Even larger amplitudes of temperature occur closer to the TexasLouisiana coast, away from the influence of the warm Loop Current and anticyclonic eddies shed by it.

A month-by-month comparison of the AVHRR-derived SSTs and the COADS SSTs for the period of overlapping observations (1983-1987) resulted in rms differences of $1.22^{\circ} \mathrm{C}$ for the western subregion ( $n=58$ months) and $0.92^{\circ} \mathrm{C}$ for the eastern subregion ( $n=60$ months). A similar comparison between the AVHRR-derived SSTs and the CAC SSTs for the same period resulted in rms differences of $0.90^{\circ} \mathrm{C}$ for the western subregion ( $n=60$ months) and $0.82^{\circ} \mathrm{C}$ for the eastern subregion ( $n=60$ months). The difference between monthly COADS SST and the satellite SST (COADS-satellite SST), ans well as the difference between monthly CAC SST and the satellite SST (CAC- satellite SST), showed a negative slope when regressed against time (slope significantly different from 0 at the 0.001 level within both subregions). There also seems to be a small phase lag between the climatological monthly values obtained from these data sets, leading to cyclic departures from a 1:1 relationship on a séasonal basis (Figure 8).

The causes for the differences among the COADS, CAC, and AVHRR SST data sets are difficult to assess. Such peculiarities may be due to effects derived from time of day at which AVHRR measurements are made (daytime passes in this case). There is also an uncertainty in the estimates associated with the fact that the AVHRR "sees" skin SST [Schluessel et al., 1990], while SST measured in situ may reflect the bulk temperature. From a climatological point of view it is possible that the Loop Current developed a more persistent intrusion into the northern gulf during the winters of 1983-1987 (years of AVHRR data) relative to previous years (COADS spanned 1946-1987), thus leading to higher winter temperatures in the eastern sector (see Figure 8).

Clearly, there is considerable scatter between pigment concentration and SST throughout the Gulf of Mexico at seasonal time scales (Figure 9). This scatter is a result of the phase difference between these variables and is evidence that algal biomass is not directly related to temperature of the water. Figure 9 emphasizes the difference in the SST range between the eastern and western subregions, while showing that pigment values in both subregions are similar during any one month. It is also clear from Figure 9 that widely different levels of algal biomass may be found at any one temperature within the SST cycle of the Gulf of Mexico. The spread in pigment values within a region is much larger during the boreal winter than during the summer.

In addition to the temporal variability observed in the surface pigment concentration, SST, and hydrographic profile series, dramatic changes in the spatial structure were 


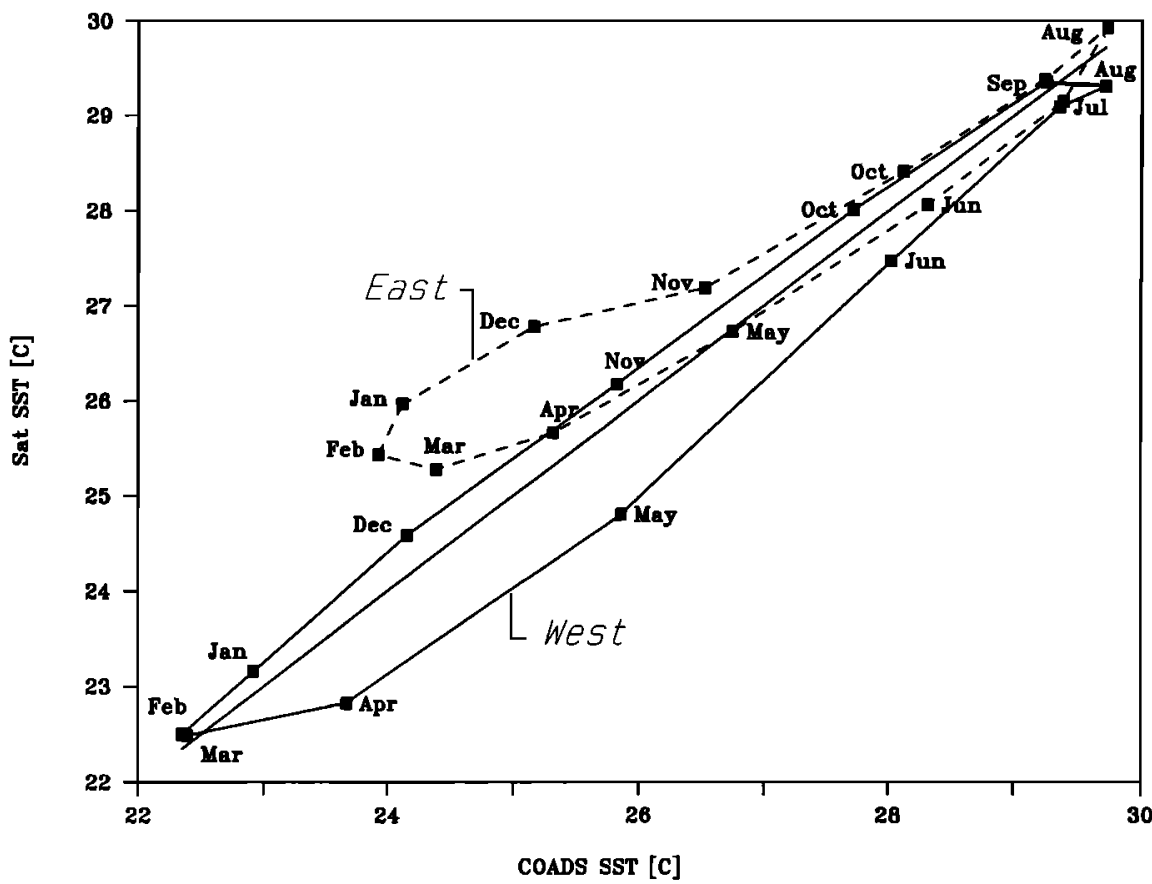

Fig. 8. Phase relation between climatological, monthly mean SST values derived from ship observations (COADS) and from the AVHRR. The two elliptical paths were obtained by comparing AVHRR-derived SST values from the subregions (Figure 1) to COADS SST values retrieved from the $2^{\circ} \times 2^{\circ}$ boxes closest to the center of the subregion of interest.

observed in the CZCS images. The series of images showed that during summer there was marked spatial structure in the pigment fields associated with the Loop Current and anticyclonic eddies (see sequences for both 1979 and 1980, Plate 1). The eastern Gulf was dominated by the clear water intrusion of the summer Loop Current, while the western side contained patches of clear water. In winter, concentrations increased simultaneously throughout the gulf, and offshore pigment fields became homogeneous between about December and February. Homogeneous fields can occur early, as was observed in late October 1979. Spatial structure did not develop again until at least February, when a tongue of low values $\left(<0.1 \mathrm{mg} \mathrm{m}^{-3}\right)$ extended into the gulf from Yucatan Channel (for example, see March to May 1979 or 1980 in Plate 1). This is also an indication of reduced domination of wind mixing and marks the lowpigment summer signature of the Loop Current.

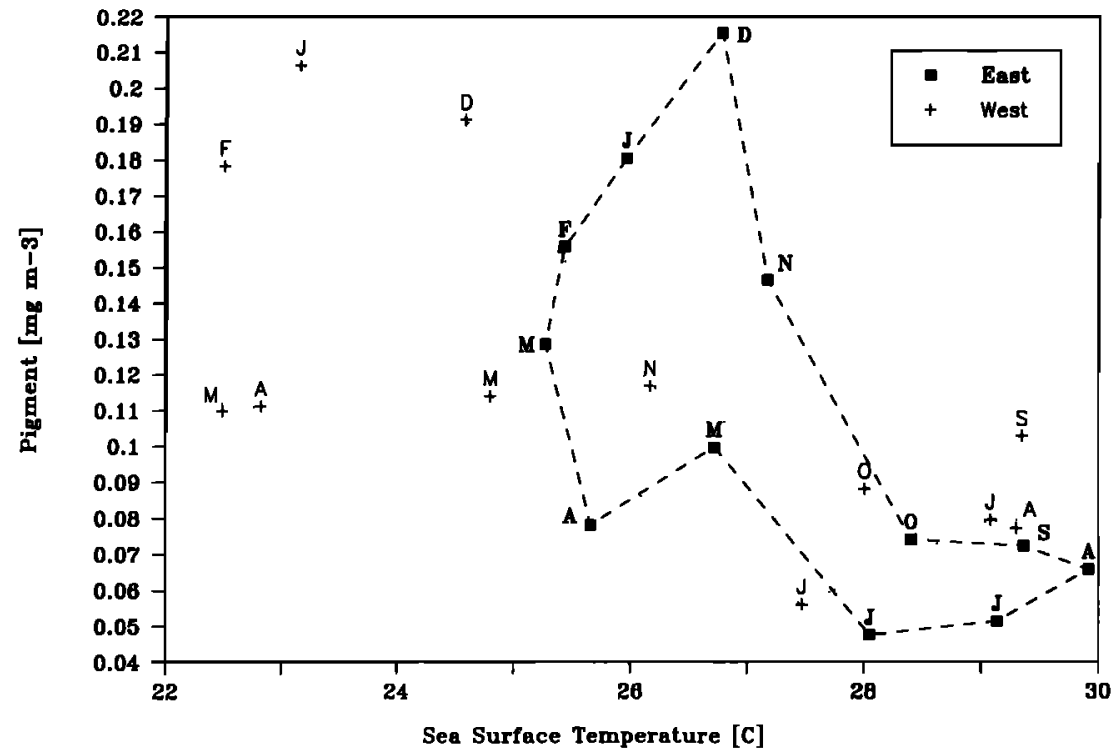

Fig. 9. Phase diagram showing the scatter in the relationship between pigment concentration and satellite-derived SST (MCSST, degrees Celsius) within two subregions of the Gulf of Mexico (see Figure 1). The dashed curve represents the seasonal cycle in the eastern Gulf of Mexico, and the dotted curve represents the variation in the western gulf. Letters represent month of the year. 


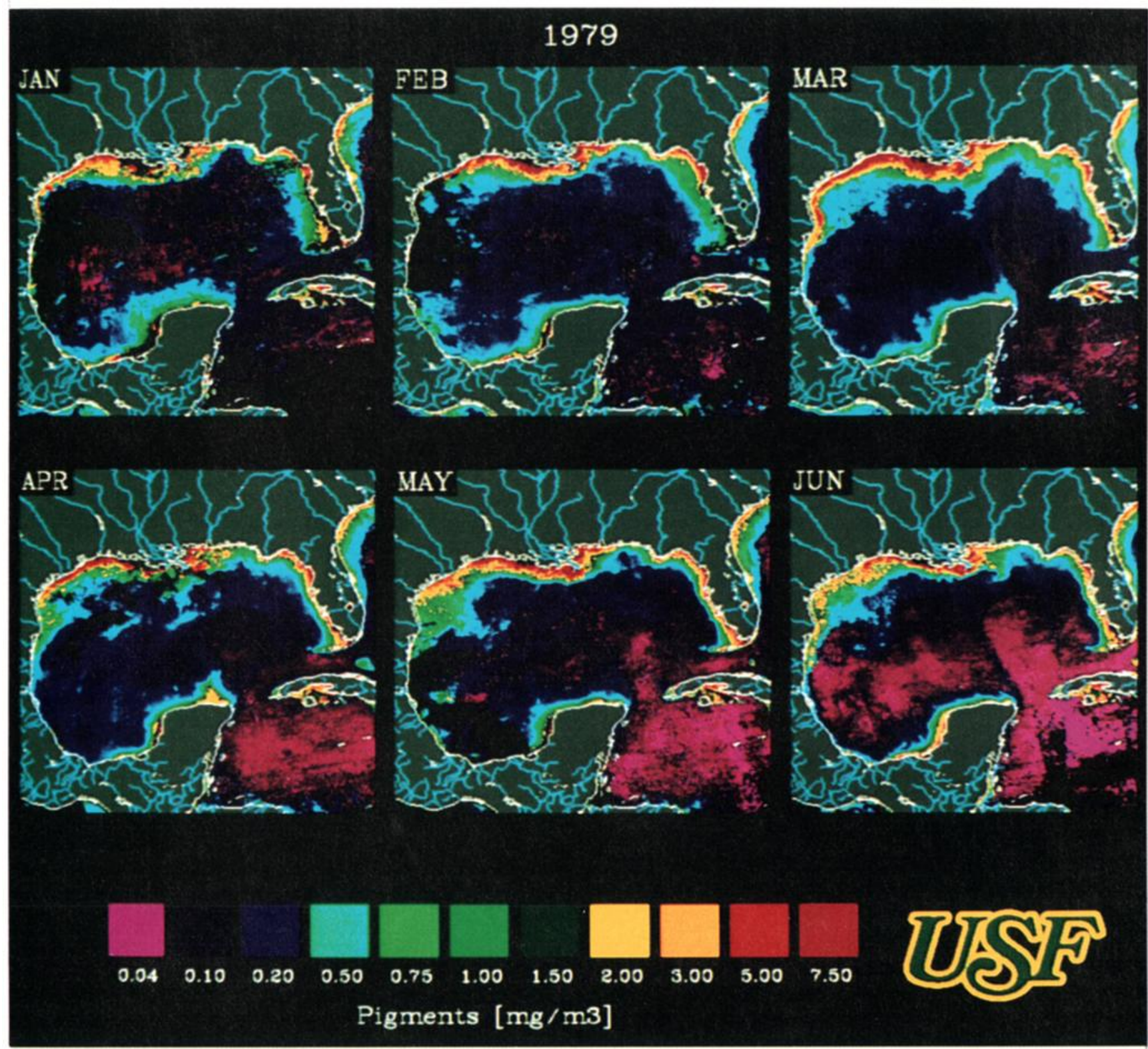

Plate 1a. Series of monthly composites of pigment concentration in the Gulf of Mexico for January to June 1979. Concentrations (milligrams per cubic meter) were color coded, with purple and blue representing low pigment concentrations (note that the lowest concentrations have been overemphasized to enhance spatial patterns using violet with a reddish tint). Yellow and red indicate higher concentrations. Land is masked grey, the coastline, white; and clouds and missing data black. Rivers affecting the region have been drawn in blue as part of the land mask for information purposes. All rivers have been drawn with the same line width, and therefore these lines do not contain information on discharge rates nor on the size of the rivers.

\section{Discussion}

Because of the large scale of the Loop Current and its anticyclonic rings and because of the variability in the occurrence, shape, and location of these features, ships alone provide inadequate definition of the circulation and biogeochemical cycling within the Gulf of Mexico. New approaches have combined models, satellites, drifters, and hydrographic and expendable bathythermograph (XBT) data to map the details of the physical environment [cf. Paskausky and Reid, 1972; Hulburt and Thompson, 1980; Science Applications International Corporation (SAIC), 1986, 1988]. In particular, infrared satellite images have provided synoptic maps of the Loop Current and its eddies since the 1970 s, something that was not possible previously even after extensive ship surveys [Lewis and Kirwan, 1987;
Vukovich, 1986, 1988a; Vukovich and Maul, 1985; Maul et al., 1985; Paluszkiewicz et al., 1983; Elliott, 1982; Maul, 1981; Vukovich et al., 1979; Huh et al., 1978, 1981]. However, infrared satellite images provide information on the spatial structure of the circulation in the Gulf only during a 7-month period (late October through mid-May). During the rest of the year, SST gradients are small throughout the gulf, rendering infrared imagery useless for identifying the summer Loop Current or other surface circulation features.

The possibilities of using remotely sensed ocean color data as a complement to infrared imagery for year-round study of surface circulation patterns in the Gulf of Mexico was first examined by Maul and Gordon [1975] and Maul [1977]. Maul and Gordon tested this concept using in situ data and images from the Earth Resources Technology Satellite ERTS 1 (the 


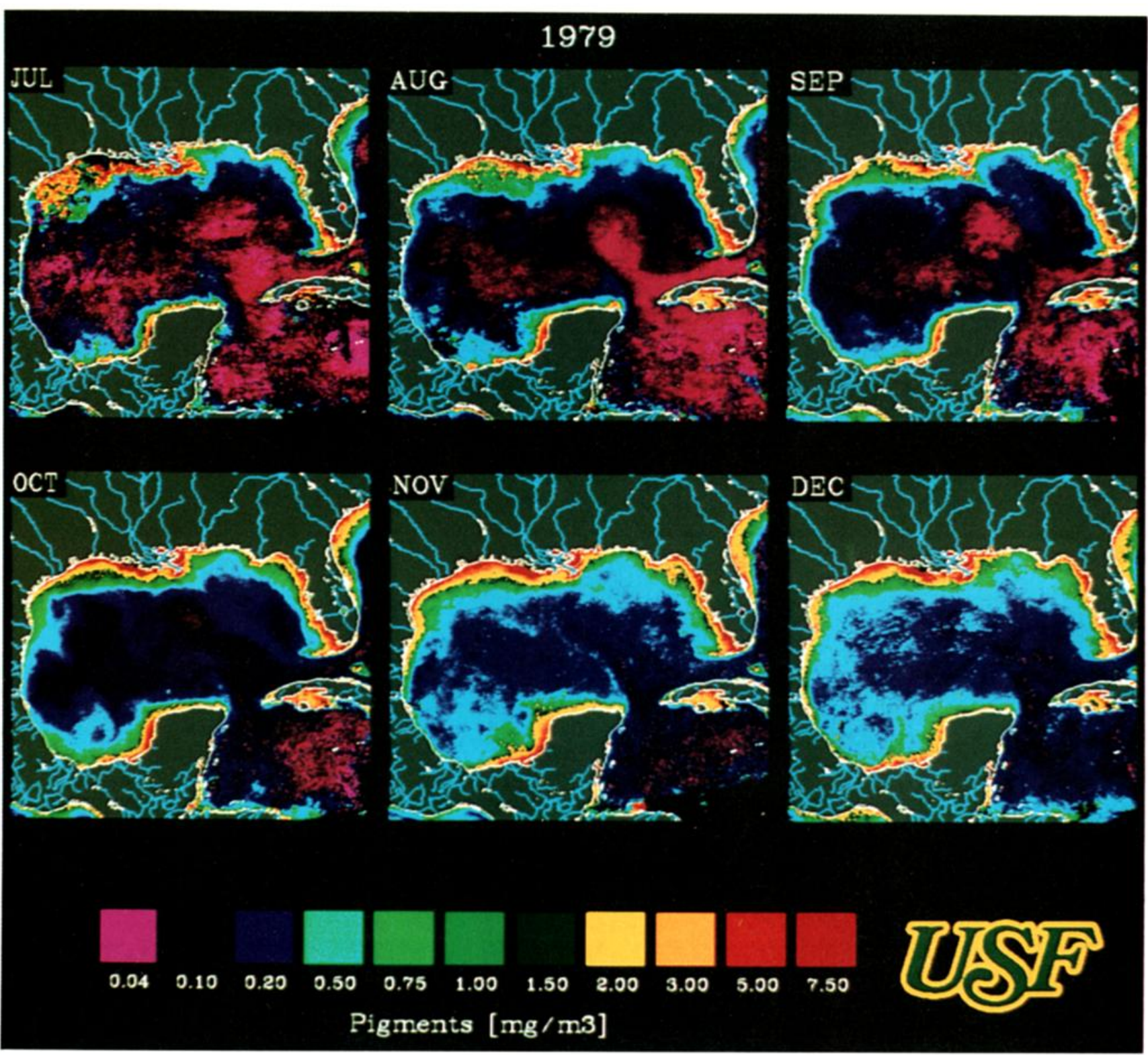

Plate $1 b$. Series of monthly composites of pigment concentration in the Gulf of Mexico for July to December 1979.

ERTS has been renamed the Landsat series). They found that the Landsat multispectral scanner (MSS) detected frontal boundaries based on changes in the color of the water, in spite of the low radiometric sensitivity (low gain) and broad wavelength channels of its sensors. Additional problems for oceanographic application are that Landsat data have very high spatial resolution (30- to $80-\mathrm{m}$ pixels) relative to the AVHRR and the CZCS ( 1-km pixels), much smaller spatial coverage $\left(\sim 300 \times 300 \mathrm{~km}^{2}\right.$ squares compared with $1000 \times$ $2000 \mathrm{~km}^{2}$ for AVHRR or CZCS), and a revisit time of 17-18 days, compared with 1-3 days for AVHRR and CZCS. Therefore Landsat data are inadequate for monitoring largescale oceanographic features like the gulf Loop Current.

The measurements and theoretical considerations of $\mathrm{Maul}$ and Gordon [1975] and subsequent efforts in the Gulf of Mexico by Clark [1981], Austin and Petzold [1981], and Austin [1980] laid the groundwork for the interpretation of the CZCS data covering this region. Here, we expand on the work of these pioneering studies to examine surface circulation patterns in the Gulf of Mexico on a year-round basis by using a combination of ocean color and infrared satellite sensors. While we recognize the importance of comparing the radiometric data provided by the CZCS with historical radiometric and Forel color observations made in the gulf, here we have limited our work to an analysis of the CZCSderived pigment concentrations.

Plate 1 and Figure 2 show that a large amount of data can be collected over the Gulf of Mexico during summer months, in spite of the rainy season. Unfortunately, the CZCS was an experimental sensor which collected data on a limited basis during its life and has not yet been replaced after finally failing in June 1986. While there is only a minimum of overlap between the AVHRR and CZCS time series, enough data exist to prove the concept, however.

The combined AVHRR and CZCS series show that the Loop Current and its anticyclonic eddies can be traced effectively during summers with the CZCS (Plate 1) and during winters with the AVHRR (Plate 2). The CZCS series also provided the first comprehensive definition of the seasonality in phytoplankton concentration within the gulf. 


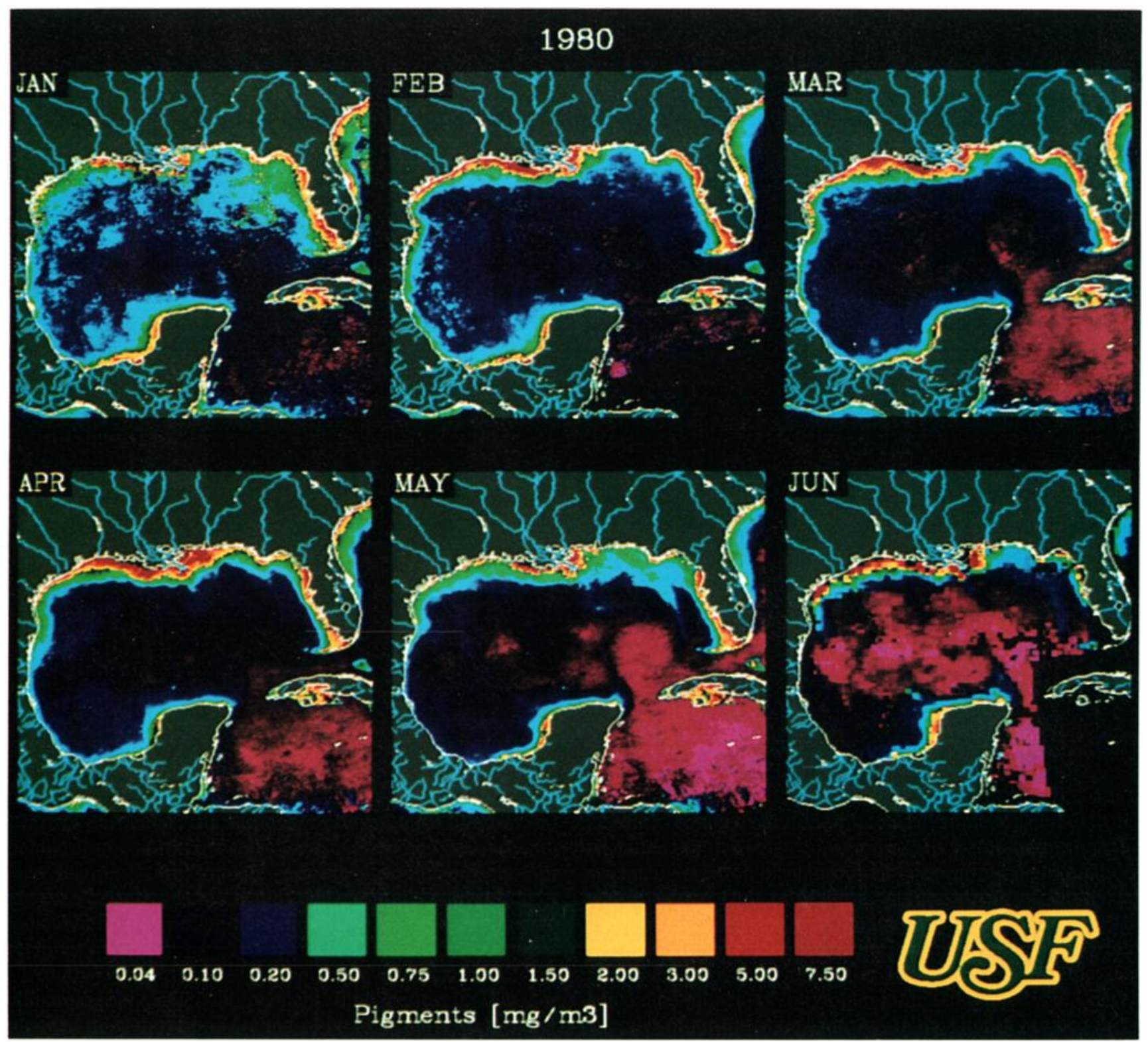

Plate 1c. Series of monthly composites of pigment concentration in the Gulf of Mexico for January to June 1980.

Using historical data, it is possible to establish which factors control such a cycle of phytoplankton concentration. While there is a long-term exchange of properties between incoming water of the Caribbean Sea and those resident in the Gulf of Mexico [Walsh et al., 1989; Kirwan et al., 1984a, $b ;$ Elliott, 1979], a comparison between long time series of physical and biological variables in the gulf suggests that on the average, the local physical processes dominate the productivity of the upper water column over the course of 1 year. In particular, the seasonal cycles of algal biomass left behind in the surface water of the eastern and western gulf (see Figure 5) are similar, regardless of the presence or absence of anticyclonic eddies and the Loop Current, as is indicated by a $3^{\circ}-4^{\circ} \mathrm{C}$ temperature contrast between the two regions (Figure 7).

Another important result from our comparison of the climatological SST and pigment time series is that the pigment concentrations are out of phase relative to the SST throughout the interior of the gulf (Figures 5 and 9). Minima of algal biomass occur 2 to 3 months before the SST maxima.
Similarly, the highest pigments occur 2 to 3 months prior to the coldest SSTs, while chlorophyll concentrations begin to decrease before SST minima occur. This lack of agreement shows not only that there is little direct impact of a $5^{\circ}-7^{\circ} \mathrm{C}$ temperature range on phytoplankton growth but that SST cannot be used to predict phytoplankton concentrations with a simple statistical model of negative correlations.

In contrast, pigment concentrations and mixed layer depth have matching phases (Figure 5). Walsh et al. [1989], using a complex coupled physical-biological numerical model, determined that the single most important factor controlling the seasonal variation of chlorophyll concentrations in offshore waters of the Gulf of Mexico was the depth of the mixed layer embodying both light limitation and nutrient availability. While downwelling, grazing, and sinking are important processes, they play a smaller role in controlling the seasonal abundance of phytoplankton stimulated by "new" supplies of nitrogen, i.e., nitrate. In the Gulf of Mexico there is adequate illumination in the mixed layer on a year-round basis. Since algal biomass is highest when the surface mixed 


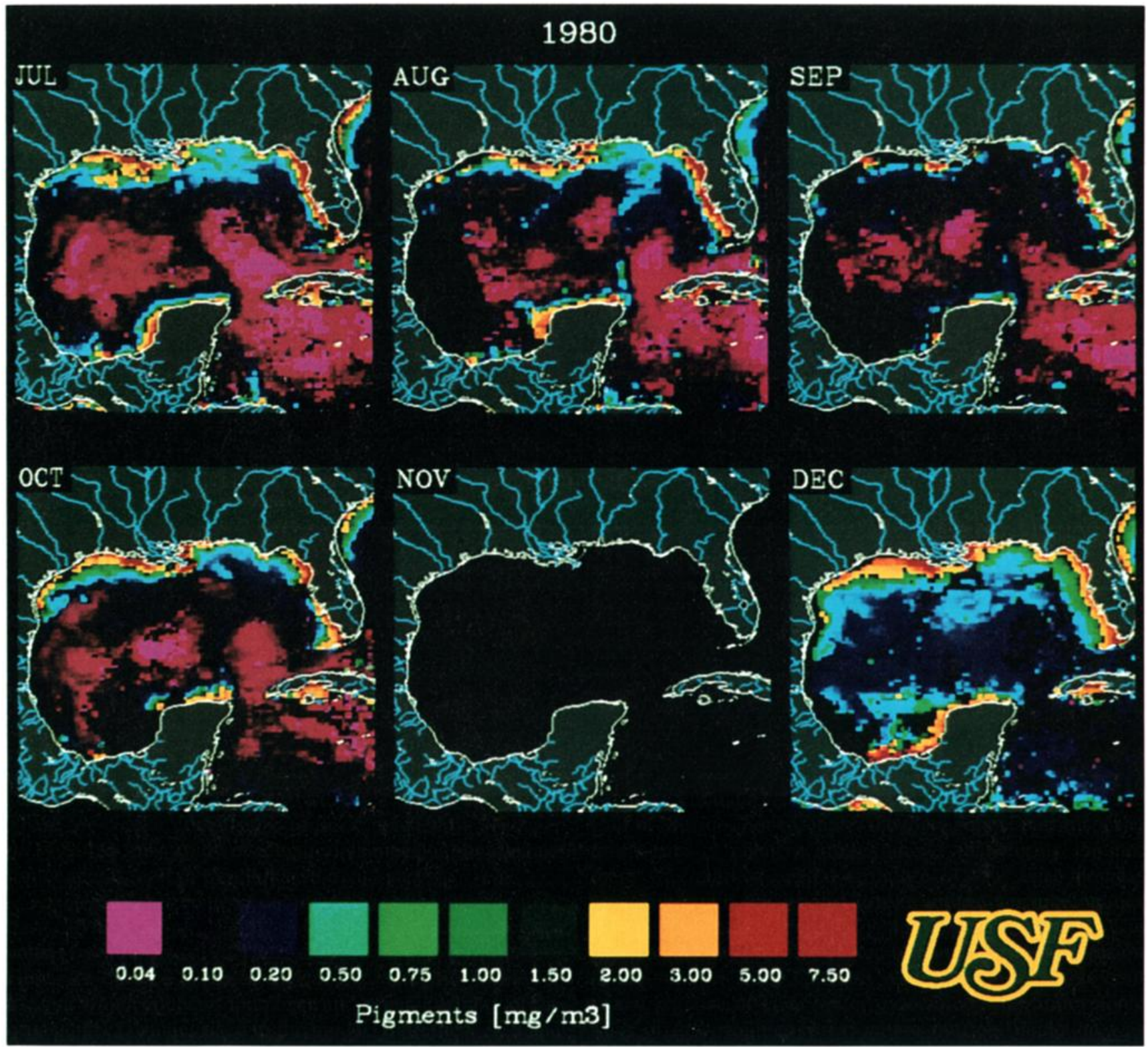

Plate $1 d$. Series of monthly composites of pigment concentration in the Gulf of Mexico for July to December 1980.

layer is deepest, this is strong evidence that primary productivity in this region is controlled by variations in upward nutrient flux. This is similar to the process observed in the Sargasso Sea by Deuser et al. [1990], Ryther and Menzel [1960], and Menzel and Ryther [1961]. Conversely, flux minima occur when stratification ensues during summers, and primary productivity is small. Further north, for example, light plays a more important role in regulating the surface blooming of phytoplankton [cf. Sverdrup, 1953]. These are similar conclusions to those reached by Marra et al. [1990] in their study of temporal changes of phytoplankton concentration in the Sargasso Sea.

The model's mixed layer depth was specified on a monthly basis [Walsh et al., 1989], using modified climatological values from Levitus [1982] at $25.5^{\circ} \mathrm{N}, 40.5^{\circ} \mathrm{W}$, in the Atlantic. Here, we derived a climatological hydrographic profile for the gulf which confirms the phase and general validity of the original MLD values used in the model. Both the CZCS and model phytoplankton concentrations were highest when the mixed layer was deepest $(125 \mathrm{~m})$ and reached a minimum simultaneously with the shallowest mixed layer $(20 \mathrm{~m})$. CZCS-derived pigment concentrations did not start to increase again appreciably until the mixed layer became deeper than about $50 \mathrm{~m}$, typically in August or September when the tropical storm and hurricane season commences (Figure 5).

When local processes of wind mixing do not dominate the surface chlorophyll field, the CZCS imagery can be used to delineate circulation features of the oligotrophic state of the Gulf of Mexico. For example, the more robust portion of the time series of pigment images shows that during summer there was marked spatial structure of low algal biomass associated with the Loop Current and anticyclonic eddies (see sequences for both 1979 and 1980 in Plate 1). The eastern gulf was then dominated by the clear water intrusion of the summer Loop Current, while the western side contained patches of clear water associated with anticyclonic rings of downwelling cores, where nutrient depletion was accentuated during summer periods of shallow mixed layers.

Such structure of the pigment fields disappeared in winter, 


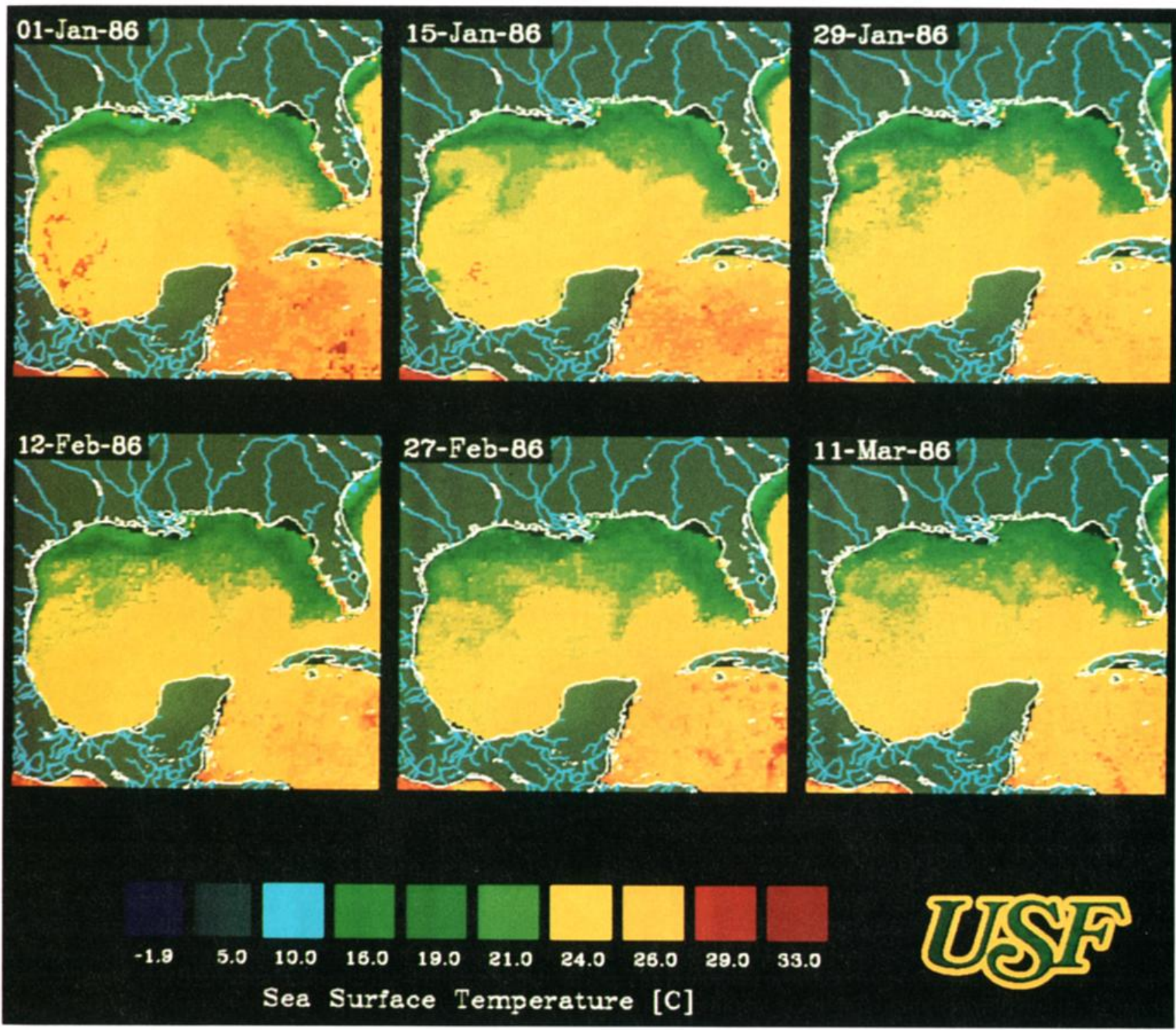

Plate 2. Sequence of 2-week mean AVHRR-derived SST fields showing both anticyclonic and cyclonic rings in winter of 1986. Land is masked grey, the coastline, white; and clouds and missing data black. Rivers affecting the region have been drawn in blue as part of the land mask for information purposes.

however, as concentrations increased simultaneously throughout the gulf (Plate 1). Offshore pigment fields became homogeneous as early as late October and did not develop spatial structure again until about February of the following year. The first indication of the development of summer patchiness occurred when a tongue of low values $(<0.1 \mathrm{mg}$ $\mathrm{m}^{-3}$ ) extended into the gulf from Yucatan Channel (for example, see March to May 1979 or 1980 in Plate 1), marking the position of the Loop Current.

In contrast, spatial structure in AVHRR images was poorly developed during summer (mid-May through October) but very well developed in winter (November through mid-May). We show examples in Plate 2 of winter SST from 1986. Clearly, AVHRR data delineate the winter circulation patterns of the Loop Current or eddies when a sufficient SST gradient occurs. Both winter and summer AVHRR-derived SST values are comparable to the COADS estimates (Figures 5,7 , and 8 ) showing that in fact the AVHRR provides a reasonable estimate of SST year-round. Further tests of this nature are necessary to decrease the rms difference between satellite and in situ SST data.

The CZCS data show marked differences between the pigment concentrations offshore in the gulf and those over the continental shelf. In general, concentrations over the shelf were always high $\left(>0.5 \mathrm{mg} \mathrm{m}^{-3}\right)$ relative to values offshore (0.2 $\mathrm{mg} \mathrm{m}^{-3}$ or less), with extremes occurring in restricted areas along the coast $\left(>5 \mathrm{mg} \mathrm{m}^{-3}\right)$. Furthermore, high concentrations of algal biomass are persistent (1) off Florida, (2) off Mississippi, Louisiana, and Texas, and (3) over Campeche Bank. Clearly, much of the shelf area of the Gulf of Mexico falls under the case II water type of Morel and Prieur [1977].

The biological productivity of the shelf is strongly affected by (1) the effluent of the Mississippi River [Walsh, 1988], (2) outflow from coastal lagoons and smaller rivers, (3) cyclonic eddies which develop along the continental margin [e.g. Biggs et al., 1984, 1991], and (4) wind-driven upwelling. Unfortunately, because of a dearth of nutrient and primary 
productivity observations at this stage, it is impossible to improve upon our prior estimate of the relative contribution of these nutrient supply mechanisms [Walsh et al., 1989].

The Mississippi River discharges, on the average, about $1.7 \times 10^{4} \mathrm{~m}^{3} \mathrm{~s}^{-1}$, with a range of $0.81 \times 10^{4} \mathrm{~m}^{3} \mathrm{~s}^{-1}$ in September to $2.81 \times 10^{4} \mathrm{~m}^{3} \mathrm{~s}^{-1}$ in April. The northern Gulf of Mexico shelf receives, in addition, the discharge of the Mobile River, at an average of $1670 \mathrm{~m}^{3} \mathrm{~s}^{-1}$, or the equivalent of $10 \%$ of the Mississippi, via Mobile Bay [Morisawa, 1968]. The Mobile River shows large variability in its discharge, and in 1980 its flood was the second largest in 20 years (R. Stumpf, U.S. Geological Survey, personal communication, 1991).

The Mississippi River discharges an average of $2.1 \times 10^{8}$ tons sediments per year [Milliman and Meade, 1983], which generally settle out of the water column, since a primary production of $>250 \mathrm{~g} \mathrm{C} \mathrm{m}^{-2} \mathrm{y}^{-1}$ occurs at the mouth of the river [Thomas and Simmons, 1960]. As a result, we are able to use riverine-induced growth of phytoplankton as a tracer of freshwater discharge on the Texas-Louisiana shelves, similar to previous studies of the plumes of the Amazon and Orinoco rivers [Müller-Karger et al., 1988, 1989].

The CZCS data clearly show that a large amount of colored material enters the Gulf of Mexico via the Mississippi delta and Mobile Bay. Furthermore, the series of CZCS images was useful for following this material and tracing the dispersal of the discharge. This was important especially because the simulated Mississippi plume dispersed toward the east in our model, a result of not being able to apply local wind forcing to the Lagrangian circulation scheme. On the basis of a few studies of the shelf in the northern gulf it has been inferred instead that the Mississippi River outflow usually spreads to the west of the delta over the continental shelf [Nowlin, 1972; Smith, 1980; Dinnel and Wiseman, 1986; Cochrane and Kelly, 1986]. As a consequence, the surface salinity fields of the Louisiana-Texas shelves exhibit a strong seasonal signal, with 15 -psu (practical salinity units) water found off the mouth of the river and $28 \mathrm{psu}$ near Brownsville, Texas, during May 1964, in contrast to 30 and $33 \mathrm{psu}$, respectively, in November 1964 [Cochrane and Kelly, 1986].

Dispersal of fresh water to the east of the Mississippi delta also occurs, however. Maul [1977], for example, during a study of the annual cycle of the Loop Current using in situ and Landsat satellite data, found a narrow band of lowsalinity water off western Florida ( $24 \mathrm{psu}$ ) and in the Straits of Florida (30 psu). He inferred that this was Mississippi River water entrained along the cyclonic edge of the Loop Current when the current penetrated northward to the vicinity of the delta. Low-salinity waters ( 34.5 psu), presumably of Mississippi origin, were reported as far north as Georgia during this period [Atkinson and Wallace, 1975].

Our time series of CZCS images confirmed both the predominant westward dispersal and occasional eastward transport of combined Mississippi and Mobile river water. Also, the CZCS data showed definite patterns in the variability of the width and length of the plume. We examined the series of daily CZCS images for the period November 1978 to May 1980 to obtain a general perception of the frequency of eastward transport of plume water. We found that eastward dispersal was sporadic and short-lived and that it covered a small area. Typically, the surface area occupied by strongly discolored water (e.g., pigment concentrations
$>1 \mathrm{mg} \mathrm{m}^{-3}$ ) derived from such events was a small fraction (typically 1-5\%) of the surface area of similarly discolored plume waters flowing westward. Eastward dispersal occurred either as a very thin $(<5-10 \mathrm{~km})$ band near the coast, as diffuse dispersal within $50 \mathbf{~ k m}$ of the coast, or as a large event in which a bolus of discolored water, over $50 \mathrm{~km}$ in diameter, moved eastward. Two such large events were detected. In each of these, water moved along the coast past Cape San Blas (Florida) and subsequently flowed south, offshore along the western Florida shelf. The first event took place in mid-March 1979, the second in late April 1980. In both cases the cycle of eastward plume transport, full extension to the Florida keys, and dissipation lasted 20-30 days.

In addition to eastward transport along the coast, small parcels of river water were also frequently observed being entrained in the cyclonic edge of the Loop Current and dispersed offshore. For example, during September to October 1979, southeastward dispersal of Mississippi water in a narrow $(20-80 \mathrm{~km})$ but long $(>900 \mathrm{~km})$ band occurred along the cyclonic edge of the Loop Current. This band could clearly be seen extending to the Dry Tortugas and being swept into the Straits of Florida on images taken on October 9 and 19, 1979. By October 24 this plume, clearly defined by concentrations of $\sim 0.2-0.4 \mathrm{mg}$ pigment $\mathrm{m}^{-3}$, flowed past Miami within a $26-\mathrm{km}$ band along the coast of southern Florida. However, by then this patch had severed from the main body of the plume near the Mississippi delta. Note that the eastward flowing feature is not clearly visible in the October 1979 monthly composite except as a faint trace of a wider $(\sim 70 \mathrm{~km})$, diffuse band of $\sim 0.2 \mathrm{mg}$ pigment $\mathrm{m}^{-3}$ along the eastern edge of the Loop Current (Plate 1). In images from mid-November 1979, mid-December 1979, and midJanuary 1980, new streamers of river water could be seen entrained in the eastern cyclonic edge of the Loop Current. These were short-lived and did not exceed about $500 \mathrm{~km}$ in length. By mid-May 1980, however, another streamer had been carried to the Straits of Florida.

It is possible that in addition to entrainment in the edge of the Loop Current during periods of northward intrusions, which may occur at any time during a year, eastward dispersal of river water is facilitated by prevailing wind patterns over the northern gulf during the first half of the year. Pechmann et al. [1986] computed the monthly winddriven transport for the Gulf of Mexico for the period 1977-1985 based on the National Weather Service limited area, fine mesh model II (LFM II) results. They show that the monthly mean wind-driven transport in the northeastern gulf is weakly north-northwestward for January through March, nil in June through September, and strongly westnorthwestward in October through December. It is conceivable that during the period of weak transport, northward wind events or northward intrusions of the Loop Current facilitate eastward movement of river water parcels. It appears that only on very rare occasions do small amounts of river water move east during the second half of the year.

Typically, however, the Mississippi-Mobile plume appeared as a massive band of high pigments extending west of Mobile Bay and the Mississippi delta along the coast. The width of the Mississippi River plume seemed to vary with seasonal changes in discharge rate: a wider plume was observed during the months of high discharge. Furthermore, 


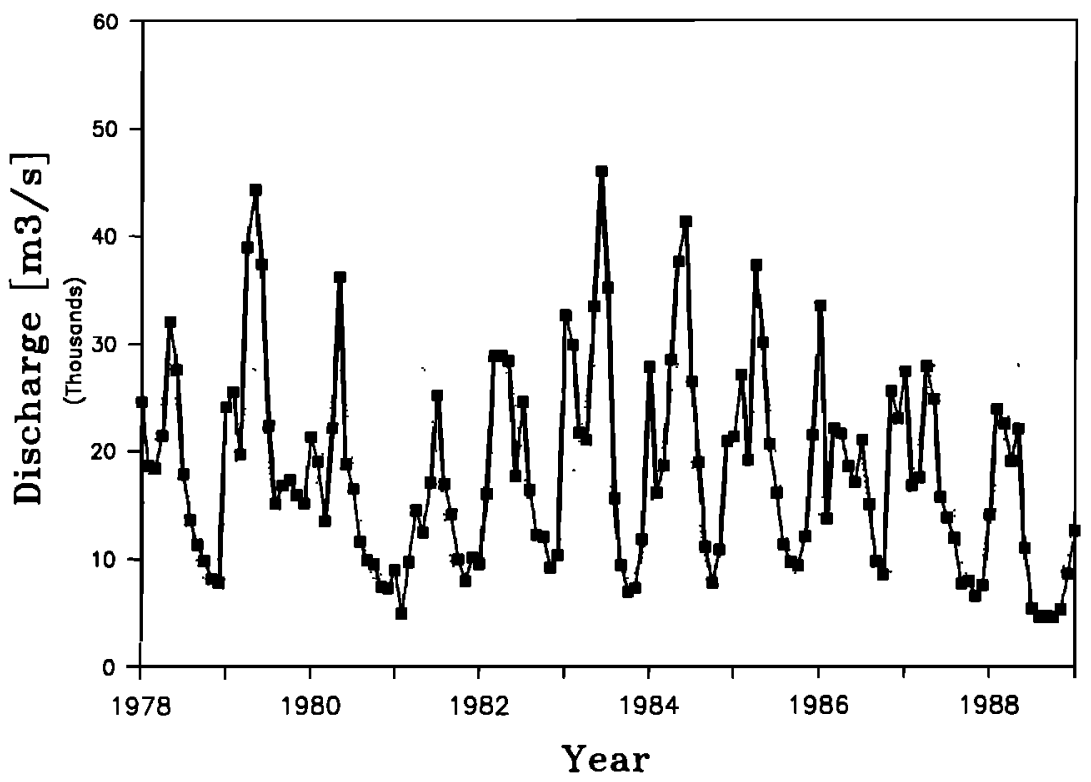

Fig. 10. Time series of monthly mean discharge (cubic meters per second) values for the Mississippi River at Vicksburg (Mississippi). The solid curve represents actual monthly mean discharge estimates. The dotted curve shows a climatology based on monthly mean discharge between 1929 and 1989.

changes in the length of the plume seemed to follow major changes in the total annual discharge.

The total annual discharge rate for the Mississippi may vary by a factor of 3 or more between years; clearly, part of the variance was embedded in our time series. For example, in 1978 and 1980 the Mississippi River flow closely followed the long-term hydrograph (Figure 10). The monthly CZCS composites for 1978 (November and December, not shown) and for 1980 (Plate 1) show that most of the discharge was carried west in a band following the coast and extending at least as far as Tampico, Mexico. The band was broadest over the shelf off Louisiana and Texas, exhibiting a crossshelf gradient in pigments. Values $>2 \mathrm{mg} \mathrm{m}^{-3}$ occurred within $5 \mathrm{~km}$ of the coast, rapidly decreasing to values around $0.5 \mathrm{mg} \mathrm{m}^{-3}$ about $30 \mathrm{~km}$ off the coast and decreasing to about $0.1 \mathrm{mg} \mathrm{m}^{-3}$ roughly $100 \mathrm{~km}$ from the coast. Off Brownsville, Texas, the band was less than $60 \mathrm{~km}$ wide.

The annual average discharge in 1979 was about 1.6 times larger than that estimated for 1978 or 1980 (Figure 10). In fact, discharge during the second half of 1979 was nearly twice that experienced during the second semester of 1980 . This was the result of at least five cyclonic storms which occurred in the gulf between July and September 1979 [Halper and Schroeder, 1990]. The higher discharge led to a longer, wider, and more persistent coastal band containing pigment values $>2 \mathrm{mg} \mathrm{m}^{-3}$ relative to the plume seen in 1980 (Plate 1).

The plume dispersal patterns in 1979 showed additional peculiarities. In contrast to the patterns seen in 1980, a large portion of the chlorophyll plume was carried offshore near the southern border of Texas starting approximately in April. The offshore movement of this plume in April to June may have been due to cyclonic eddy motions near the edge of the continental shelf. Note the cyclonic eddy depicted by the AVHRR in this region during January 15-29, 1986 (Plate 2). Similar cyclonic eddies are seen within thermal images of at least February 1984 and January 1987 (not shown here).
In addition to an offshore movement effected by a cyclonic eddy, during July to August 1979 the plume was affected by hurricane activity in the northern Gulf of Mexico. In particular, Hurricane Bob (July 9-11) formed in the southwestern Gulf of Mexico and made landfall in Louisiana, east of the Atchafalaya River mouth [Halper and Schroeder, 1990]. The Texas and Louisiana coasts were for the most part on the trailing edge (left-hand side) of the hurricane, which would have led to the offshore dispersal of coastal waters. Very high pigment concentrations are indeed seen moving offshore in this area in the July 1979 CZCS composite. Tropical storms Claudette (July 21-24) and Elena (August 29 to September 1) further helped disperse the plume offshore. Hurricane Frederic (September 10-12) then followed a track [see Halper and Schroeder, 1990] which caused a tongue of Mississippi water to wrap around the cyclonic edge of an anticyclonic eddy pinched off from the Loop Current (see below). Again in this case, the Mississippi plume was located on the trailing edge of the hurricane.

A persistent cyclone in the western Gulf of Mexico would agree with the general pattern of offshore recirculation described by Cochrane and Kelly [1986] and Dinnel and Wiseman [1986], who concluded that the fresh water from the Mississippi and Atchafalaya rivers is carried offshore off central-south Texas and then is carried back east along the shelf break. There is ample evidence for offshore flow near the Mexico-United States border: Elliott [1979] suggests that there is an eastward flow from the coast of Texas resulting from the confluence of the coastal currents moving south along Texas and north along Mexico, while Merrel and Morrison [1981] suggest that this eastward jet maintains (or is maintained by) an anticyclone/cyclone eddy pair in the western gulf. Such patterns can be related to westward motion of an anticyclone, shed by the Loop Current in the eastern gulf [Walsh et al., 1989]. The cyclonic eddies appear as the large anticyclone dissipates by friction as it interacts with the continental margin. 
As was mentioned above, the CZCS provided the first summer pictures of the Loop Current and the anticyclonic eddies it periodically sheds. These eddies are shed sometime after the Loop Current reaches its maximum northern extreme. However, the timing of penetration by the Loop Current is variable [Maul, 1977]. Also, the extent of penetration varies. For example, Nowlin and Hubertz [1972] found the northernmost extreme of the current at $28^{\circ} \mathrm{N}$, and Huh et al. [1978] found it entering De Soto Canyon and coming within $8 \mathrm{~km}$ of Pensacola Beach, Florida, on February 11, 1977. A CZCS image obtained on June 1, 1985, also clearly shows the Loop Current extending into De Soto Canyon, but most images show penetration only to less than $27^{\circ}-28^{\circ} \mathrm{N}$.

The best images of anticyclones were obtained in 1979 and 1980 (Plate 1). However, the pattern of eddy formation, movement, and dispersal in 1979 was totally different from that seen in 1980. It is unclear what effect hurricanes may have on anticyclonic eddies shed by the Loop Current, but the erratic behavior of two eddies shed during the second half of 1979 (see below) may have been a direct consequence of the unusual 1979 hurricane activity.

In the 1979 series of composites the Loop Current can be first seen in March 1979 extending to approximately $26.9^{\circ} \mathrm{N}$. Even though this feature is barely distinguished from other Gulf of Mexico waters in Plate 1, there was a difference of more than $0.05 \mathrm{mg}$ pigment $\mathrm{m}^{-3}$ between the interior of the Loop Current and other gulf waters. By April, a band of slightly elevated pigment concentration $\left(>0.1 \mathrm{mg} \mathrm{m}^{-3}\right.$ ) extended from Campeche Bank toward the Florida keys, thus severing the northern portion of the intrusion. This showed the first anticyclonic eddy of the pigment series. High-pigment waters originating from Campeche Bank also outlined the western edge of the eddy, which was approximately $400 \mathrm{~km}$ in diameter. The fate of this eddy is not clear from the CZCS data. There is a hint of lower concentrations north of Campeche Bank and west of the Loop Current in the following composite (May 1979), but it is unclear if this represents a remnant of the eddy.

The Loop Current can be seen penetrating northward again in May and June (up to $27.5^{\circ} \mathrm{N}$ ), flanked on its western side by a band of higher concentrations extending NNW from Campeche Bank for at least $500 \mathrm{~km}$. In July 1979 another eddy can be seen breaking off the northern half of the Loop Current (N-S diameter, $240 \mathrm{~km}$; E-W diameter, 380 $\mathrm{km})$. This eddy, however, appears to have been reabsorbed into the Loop Current, since the August composite shows a well-defined and fully extended Loop Current.

The August composite also shows that there is a constriction at the base of the Loop Current near $23.4^{\circ} \mathrm{N}$. This constriction leads to another shedding event, with an eddy of $\sim 320-\mathbf{k m}$ diameter seen in the September composite. In this composite the Loop Current can be seen flowing directly from Yucatan Channel to the Straits of Florida, hugging Cuba. This eddy also seems to have been reabsorbed into the Loop Current, causing a sinuous circulation pattern which extended from Yucatan Channel to $27.9^{\circ} \mathrm{N}$ in October. The Loop Current and other circulation patterns were then obscured in subsequent images of the gulf, as gradients in pigment abundance weakened.

While each of these eddies seems to have been shed and subsequently reabsorbed by the Loop Current, it is possible that only one ring was shed and that this ring continually interacted with the current without reabsorption. It is possible that mixing of near-surface waters obscured the separation zone, therefore rendering the ring indistinguishable from the Loop Current in the CZCS imagery.

During 1980 the Loop Current first became distinguishable in the March composite. By June (the first of a series of 10-day composites), much of the gulf showed extremely low concentrations $\left(<0.05 \mathrm{mg} \mathrm{m}^{-3}\right)$. This possibly was a result of widespread nutrient depletion in surface waters by phytoplankton uptake under conditions of strong water column stratification and was perhaps accentuated by westward penetration of anticyclonic eddies carrying clear water shed by the Loop Current. An anticyclonic ring shed during this period will become associated with a cyclone in a fall eddy pair off the Texas coast. In July the Loop Current was well defined, extending farther north to $27.1^{\circ} \mathrm{N}$, compared to the May position. The intrusion was then flanked to the west by a band of higher concentrations extending from Campeche to the NNW.

The Loop Current then shed another anticyclonic eddy, visible in the August 1980 composite. The eddy entrained high-pigment water from the shelf off Florida and carried it seaward to distances over $500 \mathbf{~ k m}$ offshore. The September and October 1980 composites show that the eddy drifted toward the WSW, growing in size as it was displaced. The approximate size of this second eddy and the approximate location of its center were as follows: August, $350 \mathrm{~km} \mathrm{N-S}$ diameter, $160 \mathrm{~km} \mathrm{E-W}$ diameter, centered at $25.9^{\circ} \mathrm{N}, 88^{\circ} \mathrm{W}$, with its northernmost extension at $27.5^{\circ} \mathrm{N}$; September, 330 $\mathrm{km} \mathrm{N}-\mathrm{S}$ diameter, $235 \mathrm{~km}$ E-W diameter, centered at $25.3^{\circ} \mathrm{N}$, $89.4^{\circ} \mathrm{W}$, or approximately $160 \mathrm{~km}$ from the August position; and October, $350 \mathrm{~km} \mathrm{N-S} \mathrm{diameter,} 375 \mathrm{~km}$ E-W diameter, centered at $24.7^{\circ} \mathrm{N}, 90.4^{\circ} \mathrm{W}$, or approximately $120 \mathrm{~km}$ from the September position.

This gives an approximate speed of $5 \mathrm{~km} \mathrm{~d}^{-1}$ over a period of 60 days, similar to translation velocities of other observed [Vukovich and Crissman, 1986; Kirwan et al., 1988] and simulated [Walsh et al., 1989] anticyclonic eddies in the Gulf of Mexico.

Note also in the October 1980 composite (Plate 1) that the cyclonic feature causing eastward export of a algal biomass from the Texas shelf is present again, similar to April 1979, but the first anticyclone of the eddy pair can now be seen to the southeast of the cyclone. Unfortunately, there were no data available for the first $\mathbf{1 0}$ days of November to follow the progress of either the cyclone or the two anticyclones. By December 1980 neither the Loop Current nor the eddies could be identified in the CZCS imagery because of the high uniform concentrations throughout the region. Presumably, thermal infrared satellite data would have been helpful in continuing to monitor the evolution of these features. However, we had no access to infrared data for this period.

Several oceanographers have tried to define the frequency of anticyclonic eddy shedding by the Loop Current. The general conclusion is that eddy shedding is variable. Numerical models tend to shed anticyclonic eddies at a frequency of one every 300 days, namely, at the natural frequency of the Loop Current under constant boundary conditions [see Hulburt and Thompson, 1980; Walsh et al., 1989]. Vukovich [1988b] concludes that the average eddy-shedding frequency is 10.9 months, and Behringer et al. [1977] suggested that one eddy occurs per year. The most complete eddy census was carried out by Elliott $[1979,1982]$, who concluded that 
there are years in which no eddies occur, but that up to three eddies may occur in any 1 year (as between October 1966 and June 1967). The CZCS data presented here tend to support the idea that the frequency of eddy shedding is variable. We look forward to future launches of a color sensor, providing contemporary and real-time satellite pigment and SST fields, to successfully monitor interannual cycles of Loop Current penetration and eddy shedding within the Gulf of Mexico.

\section{CONCLUSIONS}

Pigment concentration in the Gulf of Mexico undergoes a well-defined seasonal cycle which is generally synchronous throughout the region. Highest concentrations $(>0.18 \mathrm{mg}$ $\mathrm{m}^{-3}$ ) occur between December and February, and lowest values $\left(\sim 0.06 \mathrm{mg} \mathrm{m}^{-3}\right)$ occur between May and July. SST variation is also synchronous throughout the gulf, with maxima between July and September and minima in February and March. While annual cycles of algal biomass were out of phase relative to the seasonal SST cycle, the mixed layer depth and pigment concentrations showed similar phases. Model simulations show that the single most important factor controlling the seasonal cycle in surface pigment concentration is the depth of the mixed layer.

The combined use of ocean color and infrared images promises year-round observation of the spatial structure of the near-surface circulation in the Gulf of Mexico. Infrared images are most useful between November and mid-May, when strong temperature gradients occur. During this time, pigment concentrations are relatively high and typically horizontally homogeneous. Between late May and October, SST fields are uniform, however, while surface circulation features, including the Loop Current and large anticyclonic eddies, can be traced with CZCS data as very clear water bodies $\left(<0.05 \mathrm{mg}\right.$ pigment $\mathrm{m}^{-3}$ ) within more turbid waters of the Gulf of Mexico. Three anticyclonic eddies were observed in summer of 1979, and at least two were observed in summer of 1980 .

The monthly mean ocean color images show that most of the water discharged by the Mississippi and Mobile rivers flows to the west, following the Louisiana-Texas coast and at times reaching south of the Mexico-United States border. There were some single (daily) images showing that parcels of plume water can be carried east of the Mississippi delta and flow south along the western Florida shelf break. From limited data it appeared that such events have higher probability of occurring during the January to June period. On very rare occasions, small amounts of river water can move east also during the second half of the year. There were large interannual differences in the size (length and width) of the plume extending to the west consistent with variations in volume discharge.

During April 1979 and October 1980 in CZCS imagery, as well as during February 1984, January 1986, and February 1987 in AVHRR imagery, a cyclonic ring can be seen off the Texas coast, exporting high-chlorophyll and low-temperature water to the continental slope. Similar cyclonic features are found here in shipboard surveys [Biggs et al., 1991] as well as numerical models [Walsh et al., 1989]. We are presently investigating the role of cyclonic eddies in enhanced primary production within western boundary currents, where tenfold higher carbon fixation occurs, com- pared to the ambient oligotrophic water [e.g., Yoder, 1985]. Validation of complex, coupled physical-biological models requires synoptic and frequent data sets, spanning the time scales (days to years) of dominant processes.

In spite of the number of physical oceanographic studies that have been conducted in the gulf, for example, the physical processes that control ring and eddy formation [Vukovich and Maul, 1985] are still not fully understood. Similarly, the frequency of eddy shedding [Elliott, 1982; Auer, 1987] remains ill defined, and it is not clear whether the maximum northward penetration of the Loop Current is a seasonal phenomenon [Leipper, 1970; Vukovich et al., 1979; Maul, 1977; Sturges and Evans, 1983]. Acceptance of an eastern gulf forcing as a major source of variance in the physical habitat of the western gulf is a result of the last decade of satellite observations, field experiments, and numerical models. However, at this point the in situ oceanographic data set for the Gulf of Mexico is still insufficient to address questions on processes affecting the distribution of biological and chemical properties.

The next decade must provide similar data for nutrient concentrations, rates of phytoplankton and zooplankton processes, and detailed regional multidisciplinary studies. Failure to build up environmental data bases will impair progress toward understanding of the temporal and spatial variability of phytoplankton distribution in this basin and the inherent biogeochemical cycles they mediate.

Acknowledgments. We thank Gene Feldman at the Goddard Space Flight Center (NASA, Greenbelt, Maryland) for providing the data for the regional CZCS archive. We also thank Lola Olsen and Roy Jenne at the NASA Space Science Data Center (NSSDC), (Goddard Space Flight Center, Greenbelt, Maryland) for their help in accessing the COADS and CAC data sets and descriptions. We appreciate the thorough and helpful comments provided by two anonymous reviewers. Processing of the data was largely carried out on the software environment "dsp," developed at RSMAS, University of Miami, and implemented at the University of South Florida. Postprocessing and final analyses were carried out using software developed at the University of South Florida. This work was supported by the National Aeronautics and Space Administration under grant NAGW-678, by the Office of Naval Research under grant N00014-87-J-1218, and by the Department of Energy under grant OE-F605-85ER60285.

\section{REFERENCES}

Abbott, M. R., and P. M. Zion, Spatial and temporal variability of phytoplankton pigment off northern California during Coastal Ocean Dynamics Experiment 1, J. Geophys. Res., 92(C2), 1745$1755,1987$.

Atkinson, L. P., and D. Wallace, The source of unusually low surface salinities in the Gulf Stream off Georgia, Deep Sea Res., 23, 913-916, 1975.

Auer, S. J., Five-year climatological survey of the Gulf Stream system and its associated rings, J. Geophys. Res., 92(C11), 11,709-11,726, 1987.

Austin, G. B., Jr., Some recent oceanographic surveys of the Gulf of Mexico, Eos. Trans. AGU, 36(5), 885-892, 1955.

Austin, R. W., Gulf of Mexico, ocean color surface-truth measurements, Boundary Layer Meteorol., 18, 269-285, 1980.

Austin, R. W., and T. J. Petzold, The determination of the diffuse attenuation coefficient of sea water using the coastal zone color scanner, in Oceanography From Space, Proceedings of the COSPAR/SCOR/IUCRM Symposium, edited by J. F. R. Gower, pp. 239-256, Plenum, New York, 1981.

Baker, K. S., and R. C. Smith, Bio-optical classification and model of natural waters, Limnol. Oceanogr., 27, 500-509, 1982.

Barale, V., C. R. McClain, and P. Malanotte-Rizzoli, Space and 
time variability of the surface color field in the northern Adriatic Sea, J. Geophys. Res., 9I(C11), 12,957-12,974, 1986.

Behringer, D. W., R. L. Molinari, and J. F. Festa, The variability of anticyclonic current patterns in the Gulf of Mexico, J. Geophys. Res., 82(34), 5469-5476, 1977.

Biggs, D. C., D. E. Smith, R. R. Bidigare, and M. A. Johnson, In situ estimation of the population density of gelatinous planktivores in Gulf of Mexico surface waters, in Divers, Submersibles, and Marine Science, Occas. Pap. Biol., no. 9, edited by N. C. Fleming, pp. 17-34, Memorial University of Newfoundland, St. John's, Canada, 1984.

Biggs, D. C., A. C. Vastano, R. A. Ossinger, A. G. Zurita, and A. P. Franco, Multidisciplinary study of warm- and cold-core rings in the Gulf of Mexico, in The Role of Fishing and Aquaculture in the Development of Rural Areas of the Caribbean, edited by J. Buitriago and R. Margalef, La Salle Foundation, Caracas, Venezuela, in press, 1991.

Blumberg, A. F., and G. L. Mellor, A simulation of the circulation in the Gulf of Mexico, Isr. J. Earth Sci., 34, 122-144, 1985.

Campbell, J. W., and J. E. O'Reilly, Role of satellites in estimating primary productivity on the Northwest Atlantic continental shelf, Cont. Shelf Res., 8, 179-204, 1988.

Carder, K. L., R. G. Steward, J. H. Paul, and G. A. Vargo, Relationships between chlorophyll and ocean color constituents as they affect remote-sensing reflectance models, Limnol. Oceanogr., 31(2), 403-413, 1986.

Carder, K. L., R. G. Steward, G. R. Harvey, and P. B. Ortner, Marine humic and fulvic acids: Their effects on remote sensing of ocean chlorophyll, Limnol. Oceanogr., 34(1), 68-81, 1989.

Clark, D. K., Phytoplankton pigment algorithms for the Nimbus-7 CZCS, in Oceanography From Space, Proceedings of the COSPAR/SCOR/IUCRM Symposium, edited by J. F. R. Gower, pp. 227-237, Plenum, New York, 1981.

Cochrane, J. D., and F. J. Kelly, Low-frequency circulation on the Texas-Louisiana continental shelf, J. Geophys. Res., 91(C9), 10,645-10,659, 1986.

Deuser, W. G., F. E. Müller-Karger, R. H. Evans, O. B. Brown, W. E. Esaias, and G. C. Feldman, Surface-ocean color and deep-ocean carbon flux: How close a connection?, Deep Sea Res., 37(8), 1331-1343, 1990.

Dinnel, S. P., and W. J. Wiseman, Jr., Fresh water on the Louisiana and Texas shelf, Cont. Shelf Res., 6, 765-784, 1986.

Elliott, B. A., Anticyclonic rings and the energetics of the circulation in the Gulf of Mexico, Ph.D. dissertation, Tex. A\&M Univ., College Station, 1979.

Elliott, B. A., Anticyclonic rings in the Gulf of Mexico, J. Phys Oceanogr., 12, 1291-1309, 1982.

El-Sayed, S. Z., and C. C. Trees, Ecological studies of phytoplankton in the Gulf of Mexico during NOAA/NMFS Oregon II cruise Tech. Rep., 80-8-T, 53 pp., Tex. A\&M Univ., College Station, 1980.

Feldman, G., et al., Ocean color, availability of the global data set, Eos Trans. AGU, 70(23), 634, 1989.

Fisher, J., R. Doerffer, and H. Grassl, Factor analysis of multispectral radiances over coastal and open ocean water based on radiative transfer calculations, Appl. Opt., 25(3), 446-456, 1986.

Gordon, H. R., D. K. Clark, J. L. Mueller, and W. A. Hovis, Phytoplankton pigments derived from the Nimbus-7 CZCS: Comparison with surface measurements, Science, 210, 63-66, 1980.

Gordon, H. R., D. K. Clark, J. W. Brown, O. B. Brown, and R. H Evans, Satellite measurement of the phytoplankton pigment concentration in the surface waters of a warm core Gulf Stream ring, J. Mar. Res., 40(2), 491-502, 1982.

Gordon, H. R., D. K. Clark, J. W. Brown, O. B. Brown, R. H. Evans, and W. W. Broenkow, Phytoplankton pigment concentrations in the Middle Atlantic Bight: Comparison of ship determinations and CZCS estimates, Appl. Opt., 22, 20-35, 1983a.

Gordon, H. R., J. W. Brown, O. B. Brown, R. H. Evans, and D. K. Clark, Nimbus 7 CZCS: Reduction of its radiometric sensitivity with time, Appl. Opt., 22, 3929-3931, $1983 b$.

Gordon, H. R., O. B. Brown, R. H. Evans, J. W. Brown, R. C. Smith, K. S. Baker, and D. K. Clark, A semianalytic radiance model of ocean color, J. Geophys. Res., 93(D9), 10,909-10,924, 1988.

Halper, F. B., and W. W. Schroeder, The response of shelf waters to the passage of tropical cyclones-Observations from the Gulf of Mexico, Cont. Shelf Res., 10, 8, 777-793, 1990.

Hofmann, E. E., and S. J. Worley, An investigation of the circulation of the Gulf of Mexico, J. Geophys. Res., 91, 14,221-14,236, 1986.

Huh, O. K., W. J. Wiseman, and L. J. Rouse, Jr., Winter cycle of sea surface thermal patterns, northeastern Gulf of Mexico, $J$. Geophys. Res., 83, 4523-4529, 1978.

Huh, O. K., W. J. Wiseman, and L. J. Rouse, Jr., Intrusion of Loop Current waters onto the west Florida continental shelf, J. Geophys. Res., 86, 4186-4192, 1981.

Hulburt, H. E., and J. D. Thompson, A numerical study of Loop Current intrusions and eddy shredding, J. Phys. Oceanogr., 10, 1611-1651, 1980.

Kirwan, A. D., Jr., W. J. Merrell, Jr., J. K. Lewis, and R. E. Whitaker, Lagrangian observations of an anticyclonic eddy in the western Gulf of Mexico, J. Geophys. Res., 89(C3), 3417-3424, $1984 a$.

Kirwan, A. D., Jr., W. J. Merrell, Jr., J. K. Lewis, R. E. Whitaker, and $\mathbf{R}$. Legeckis, A model for the analysis of drifter data with an application to a warm core eddy in the Gulf of Mexico, $J$. Geophys. Res., 89(C3), 3425-3438, $1984 b$.

Kirwan, A. D., J. K. Lewis, A. W. Indest, P. Reinersman, and I. Quintero, Observed and simulated kinematic properties of Loop Current rings, J. Geophys. Res., 93(C2), 1189-1198, 1988.

Leipper, D., A sequence of current patterns in the Gulf of Mexico, J. Geophys. Res., 75(3), 637-657, 1970.

Levitus, S., Climatological atlas of the world ocean, NOAA Prof. Pap. 13, 173 pp., U.S. Dep. Comm., Rockville, Md., 1982.

Lewis, J. K., and A. D. Kirwan, Jr., Genesis of a Gulf of Mexico ring as determined from kinematic analyses, J. Geophys. Res., 92(C11), 11,727-11,740, 1987.

Marra, J., R. R. Bidigare, and T. D. Dickey, Nutrients and mixing, chlorophyll and phytoplankton growth, Deep Sea Res., 37(1) 127-143, 1990.

Maul, G. A., The annual cycle of the Gulf Loop Current, I, Observations during a one-year time series, J. Mar. Res., 35(1), 29-47, 1977.

Maul, G. A., Application of GOES visible-infrared data to quantifying mesoscale ocean surface temperatures, J. Geophys. Res., 86(C9), 8077-8021, 1981.

Maul, G. A., and H. R. Gordon, On the use of the Earth Resources Technology Satellite (Landsat-1) in optical oceanography, $R e$ mote Sens. Environ., 4, 95-128, 1975.

Maul, G. A., F. Williams, M. Roffer, and F. M. Sousa, Remotely sensed oceanography patterns and variability of bluefin tuna catch in the Gulf of Mexico, Oceanol. Acta, 7(4), 469-479, 1984.

Maul, G. A., D. A. Mayer, and S. R. Baig, Comparisons between a continuous 3-year current-meter observation at the sill of the Yucatan Strait, satellite measurements of gulf Loop Current area, and regional sea level, J. Geophys. Res., 90(C5), 9089-9096, 1985.

McClain, C. R., W. E. Esaias, G. C. Feldman, J. Elrod, D. Endres, J. Firestone, M. Darzi, R. Evans, and J. Brown, Physical and biological processes in the North Atlantic during the First GARP Global Experiment, J. Geophys. Res., 95(C10), 18,027-18,048, 1990.

McClain, E. P., W. G. Pichel, C. C. Walton, Z. Ahmad, and J. Sutton, Multi-channel improvements to satellite-derived global sea-surface temperatures, Adv. Space Res., 2(6), 43-47, 1983.

McClain, E. P., W. G. Pichel, and C. C. Walton, Comparative performance of AVHRR-based multichannel sea surface temperatures, J. Geophys. Res., 90(C6), 11,587-11,601, 1985.

Menzel, D. W., and J. H. Ryther, Annual variations in primary production of the Sargasso Sea off Bermuda, Deep Sea Res., 7, 282-288, 1961.

Merrel, W. J., and J. M. Morrison, On the circulation of the western Gulf of Mexico with observations from April 1978, J. Geophys. Res., 86(C5), 4181-4185, 1981.

Milliman, J. D., and R. H. Meade, World-delivery of river sediment to the oceans, J. Geol., 91(1), 1-21, 1983.

Morel, A., and L. Prieur, Analysis of variations in ocean color, Limnol. Oceanogr., 22, 709-722, 1977.

Morisawa, M., Streams, Their Dynamics, and Morphology, 175 pp., McGraw-Hill, New York, 1968.

Mueller, J. L., Nimbus-7 CZCS: Electronic overshoot due to cloud reflectance, Appl. Opt., 27, 438-440, 1988. 
Müller-Karger, F. E., C. R. McClain, and P. L. Richardson, The dispersal of the Amazon's water, Nature, 333, 56-59, 1988.

Müller-Karger, F. E., C. R. McClain, T. R. Fisher, W. E. Esaias, and $\mathbf{R}$. Varela, Pigment distribution in the Caribbean Sea: Observations from space, Prog. Oceanogr., 23, 23-69, 1989.

Müller-Karger, F. E., C. R. McClain, R. N. Sambrotto, and C. G. Ray, Measurements of phytoplankton distribution in the southeastern Bering Sea using the CZCS: A note of caution, $J$. Geophys. Res., 95(C7), 11,483-11,499, 1990.

Nowlin, W. D., Jr., Winter circulation patterns and property distributions, in Contributions on the Physical Oceanography of the Gulf of Mexico, Tex. A\&M Univ. Oceanogr. Stud., vol. 2, edited by L. R. A. Capurro and J. L. Reid, chap. 1, pp. 3-51, Gulf, Houston, Tex., 1972.

Nowlin, W. D., Jr., and J. M. Hubertz, Contrasting summer circulation patterns for the eastern gulf, in Contributions on the Physical Oceanography of the Gulf of Mexico, Tex. A\&M Univ. Oceanogr. Stud., vol. 2, edited by L. R. A. Capurro and J. L. Reid, chap. 6, pp. 119-137, Gulf, Houston, Tex., 1972.

Nowlin, W. D., Jr., J. M. Hubertz, and R. O. Reid, A detached eddy in the Gulf of Mexico, J. Mar. Res., 26(2), 185-186, 1968.

Olson, D. G., G. P. Podesta, R. H. Evans, and O. B. Brown, Temporal variations in the separation of Brazil and Malvinas currents, J. Geophys. Res., 35(12), 1971-1990, 1988.

Ortner, P. B., R. L. Ferguson, S. R. Piotrowicz, L. Chesal, G. A. Berberian, and A. V. Palumbo, Biological consequences of hydrographic and atmospheric advection within the Gulf Loop Intrusion, Deep Sea Res., 31, 1101-1120, 1984.

Paluszkiewicz, T., L. P. Atkinson, E. S. Posmentier, and C. R. McClain, Observations of a Loop Current frontal eddy intrusion onto the west Florida shelf, J. Geophys. Res., 88(C14), 9639 9651, 1983.

Paskausky, D. F., and R. O. Reid, A barotropic prognostic numerical circulation model, in Contributions on the Physical Oceanography of the Gulf of Mexico, Tex. A\&M Univ. Oceanogr. Stud., vol. 2, edited by L. R. A. Capurro and J. L. Reid, chap. 10, pp. 163-176, Gulf, Houston, Tex., 1972.

Pechmann, K. B., J. O. Ellis, F. G. Everdale, S. Z. Green, I. C. Sheifer, and M. K. Stern, Marine Environmental Assessment, Gulf of Mexico 1985 Annual Summary, pp. 49-55, U.S. Department of Commerce, Washington, D. C., 1986.

Reynolds, R. W., A real-time global sea surface temperature analysis, J. Clim., 1, 75-86, 1988.

Reynolds, R. W., and L. Roberts, Global sea-surface temperature climatology from in-situ, satellite, and ice data, Trop. OceanAtmos. Newsl., 37, 15-17, 1987.

Robinson, M. K., Atlas of monthly mean sea surface and subsurface temperature and depth of the top of the thermocline: Gulf of Mexico and Caribbean Sea, Ref. 73-8, 105 pp., Scripps Inst. of Oceanogr., La Jolla, Calif., 1973.

Ryther, J. H., and D. W. Menzel, The seasonal and geographical range of primary production in the western Sargasso Sea, Deep Sea Res., 6, 235-238, 1960.

Schluessel, P., W. J. Emery, H. Grassl, and T. Mammen, On the bulk-skin temperature difference and its impact on satellite remote sensing of sea surface temperature, J. Geophys. Res., 95(C8), 13,341-13,356, 1990.

Schroeder, W. W., L. Berner, Jr., and W. D. Nowlin, Jr., The oceanic waters of the Gulf of Mexico and Yucatan Strait during July 1969, Bull. Mar. Sci., 24, 1-19, 1974.

Science Applications International Corporation (SAIC), Gulf of Mexico physical oceanography program, final report: Years 1 and 2, vol. II, OCS Rep. MMS 85-0094, 378 pp., Gulf of Mex. Reg. Off., Miner. Manage. Serv., U.S. Dep. of the Inter., New Orleans, La., 1986.

Science Applications International Corporation (SAIC), Gulf of Mexico physical oceanography program, final report: Year 3, vol. II, OCS Rep. MMS 88-0046, 241 pp., Gulf of Mex. Reg. Off., Miner. Manage. Serv., U.S. Dep. of the Interior, New Orleans, La., 1988.
Smith, N. P., On the hydrography of shelf waters off the central Texas Gulf Coast, J. Phys. Oceanogr., 10, 806-813, 1980.

Strong, A. E., and E. P. McClain, Improved ocean surface temperatures from space, Comparisons with drifting buoys, Bull. Am. Meteorol. Soc., 65(2), 138-142, 1984.

Sturges, W., and J. P. Blaha, A western boundary current in the Gulf of Mexico, Science, 192, 367-369, 1976.

Sturges, W., and J. C. Evans, On the variability of the Loop Current in the Gulf of Mexico, J. Mar. Res., 4I(4), 639-653, 1983.

Sverdrup, H. U., On conditions for the vernal blooming of phytoplankton, J. Cons. Int. Explor. Mer., 18, 287-295, 1953.

Thomas, W. H., and G. Simmons, Phytoplankton production in the Mississippi delta, in Recent Sediments, Northwest Gulf of Mexico, edited by F. P. Shepard, F. B. Phleger, and T. H. van Andel, pp. 103-116, American Association of Petroleum Geologists, Tulsa, Okla., 1960.

Trees, C. C., Remote sensing of ocean color in the northern Gulf of Mexico, Ph.D. dissertation, 258 pp., Tex. A\&M Univ., College Station, 1985.

Vukovich, F. M., Aspects of the behavior of cold perturbations in the eastern Gulf of Mexico: A case study, J. Phys. Oceanogr., 18, 1051-1059, 1986.

Vukovich, F. M., On the formation of elongated cold perturbations off the Dry Tortugas, J. Phys. Oceanogr., 18, 1051-1059, 1988a.

Vukovich, F. M., Loop Current boundary variations, J. Geophys. Res., 93(C12), 15,585-15,591, $1988 b$.

Vukovich, F. M., and B. W. Crissman, Aspects of warm rings in the Gulf of Mexico, J. Geophys. Res., 91(C2), 2645-2660, 1986.

Vukovich, F. M., and G. A. Maul, Cyclonic eddies in the eastern Gulf of Mexico, J. Phys. Oceanogr., 15, 105-117, 1985.

Vukovich, F. M., B. W. Crissman, M. Bushnell, and W. J. King, Some aspects of the oceanography of the Gulf of Mexico using satellite and in situ data, J. Geophys. Res., 84(C12), 7749-7768, 1979.

Walsh, J. J., On the Nature of Continental Shelves, 508 pp., Academic, San Diego, Calif., 1988.

Walsh, J. J., D. A. Dieterle, M. B. Meyers, and F. E. MüllerKarger, Nitrogen exchange at the continental margin: A numerical study of the Gulf of Mexico, Prog. Oceanogr., 23, 248-301, 1989.

Walton, C. C., Nonlinear multichannel algorithms for estimating sea surface temperature with AVHRR satellite data, J. Appl. Meteorol., 27, 115-127, 1988.

Wert, R. T., and R. O. Reid, A baroclinic prognostic numerical circulation model, in Contributions on the Physical Oceanography of the Gulf of Mexico, Tex. A\&M Univ. Oceanogr. Stud., vol. 2, edited by L. R. A. Capurro and J. L. Reid, chap. 11, pp. 177-209, Gulf, Houston, Tex., 1972.

Woodruff, S. D., R. J. Slutz, R. L. Jenne, and P. M. Steurer, A comprehensive ocean-atmosphere data set, Bull. Am. Meteorol. Soc., 68, 1239-1250, 1987.

Yoder, J. A., Environmental control of phytoplankton production in the southeastern U.S. continental shelf, in Oceanography of the Southeastern U.S. Continental Shelf, Coastal Estuarine Sci., vol. 2, edited by L. P. Atkinson, D. W. Menzel, and K. A. Bush, pp. 93-103, AGU, Washington, D. C., 1985.

Yoder, J. A., C. R. McClain, J. O. Blanton, and L.-Y. Oey, Spatial scales in CZCS-chlorophyll imagery of the southeastern U.S. continental shelf, Limnol. Oceanogr., 32(4), 929-941, 1987.

R. H. Evans, Rosenstiel School of Marine and Atmospheric Science, University of Miami, 4600 Rickenbacker Causeway, Miami, FL 33149.

M. B. Meyers, F. E. Müller-Karger, and J. J. Walsh, Department of Marine Science, University of South Florida, 140 Seventh Avenue South, St. Petersburg, FL 33701.

(Received November 13, 1990; accepted December 12, 1990.) 